\title{
Aspalathin from Rooibos (Aspalathus linearis): A Bioactive C-glucosyl Dihydrochalcone with Potential to Target the Metabolic Syndrome
}

\author{
Authors \\ Elizabeth Joubert ${ }^{3,4}$ \\ Affiliations \\ 1 Biomedical Research and Innovation Platform (BRIP), \\ Medical Research Council (MRC), Tygerberg, South Africa \\ 2 Division of Medical Physiology, Faculty of Health Sciences, \\ Stellenbosch University, Tygerberg, South Africa \\ 3 Plant Bioactives Group, Post-Harvest and Agro-Processing \\ Technologies, Agricultural Research Council (ARC), \\ Infruitec-Nietvoorbij, Stellenbosch, South Africa \\ 4 Department of Food Science, Stellenbosch University, \\ Stellenbosch, South Africa \\ 5 Department of BioMolecular Sciences, Division of Pharma- \\ cognosy and the Research Institute of Pharmaceutical \\ Sciences, School of Pharmacy, The University of \\ Mississippi, Oxford, Mississippi, United States \\ 6 Department of Biochemistry and Microbiology, University \\ of Zululand, Kwadlangezwa, South Africa
}

Rabia Johnson ${ }^{1,2}$, Dalene de Beer ${ }^{3,4}$, Phiwayinkosi V. Dludla ${ }^{1,2}$, Daneel Ferreira ${ }^{5}$, Christo J. F. Muller ${ }^{1,2,6}$,

Key words

Aspalathus linearis, Fabaceae, aspalathin, metabolic syndrome, oxidative stress, molecular mechanism, bioavailability, herb-drug interactions

received November 10, 2017

revised December 19, 2017

accepted December 28, 2017

Bibliography

DOI https://doi.org/10.1055/s-0044-100622

Published online January 31, 2018 | Planta Med 2018; 84: 568-583 @ Georg Thieme Verlag KG Stuttgart · New York I ISSN 0032-0943

\section{Introduction}

Mounting evidence that dietary polyphenols may modulate dysglycaemia, a major metabolic aberration associated with the development of type 2 diabetes, is rooted in the demonstration by Von Mering in 1886 that high doses of the dihydrochalcone phloridzin ( 2 '- $\beta$-D-glucopyranosyloxyphloretin) reduced glucose reabsorption from the renal filtrate, causing glucosuria in dogs and lat-
Correspondence

Prof. Elizabeth Joubert

Plant Bioactives Group, Post-Harvest and Agro-Processing

Technologies, Agricultural Research Council (ARC), Infruitec-

Nietvoorbij

Private Bag X5026, Stellenbosch 7599, South Africa

Phone: + 27218093444 , Fax: + 27218093430

JoubertL@arc.agric.za

\section{ABSTRACT}

Aspalathin is a C-glucosyl dihydrochalcone that is abundantly present in Aspalathus linearis. This endemic South African plant, belonging to the Cape Floristic region, is normally used for production of rooibos, a herbal tea. Aspalathin was valued initially only as precursor in the formation of the characteristic red-brown colour of "fermented" rooibos, but the hype about the potential role of natural antioxidants to alleviate oxidative stress, shifted interest in aspalathin to its antioxidant properties and subsequently, its potential role to improve metabolic syndrome, a disease condition interrelated with oxidative stress. The potential use of aspalathin or aspalathin-rich rooibos extracts as a condition-specific nutraceutical is hampered by the limited supply of green rooibos (i.e., "unfermented" plant material) and low levels in "fermented" rooibos, providing incentive for its synthesis. In vitro and in vivo studies relating to the metabolic activity of aspalathin are discussed and cellular mechanisms by which aspalathin improves glucose and lipid metabolism are proposed. Other aspects covered in this review, which are relevant in view of the potential use of aspalathin as an adjunctive therapy, include its poor stability and bioavailability, as well as potential adverse herb-drug interactions, in particular interference with the metabolism of certain commonly prescribed chronic medications for hyperglycaemia and dyslipidaemia. er also confirmed in humans [1]. This earned phloridzin the distinction as "the only compound known to have a definite action in man" as stated in a book chapter on the economic importance of flavonoid compounds in foodstuffs, published in 1962 [2]. Since the discovery of Von Mering, studies on phloridzin have progressed to the development of C-glucosyl analogues, not only with longer pharmacokinetic half-lives and duration of action than O-glucosides, but with high selectivity for SGLT2 over SGLT1 (re- 


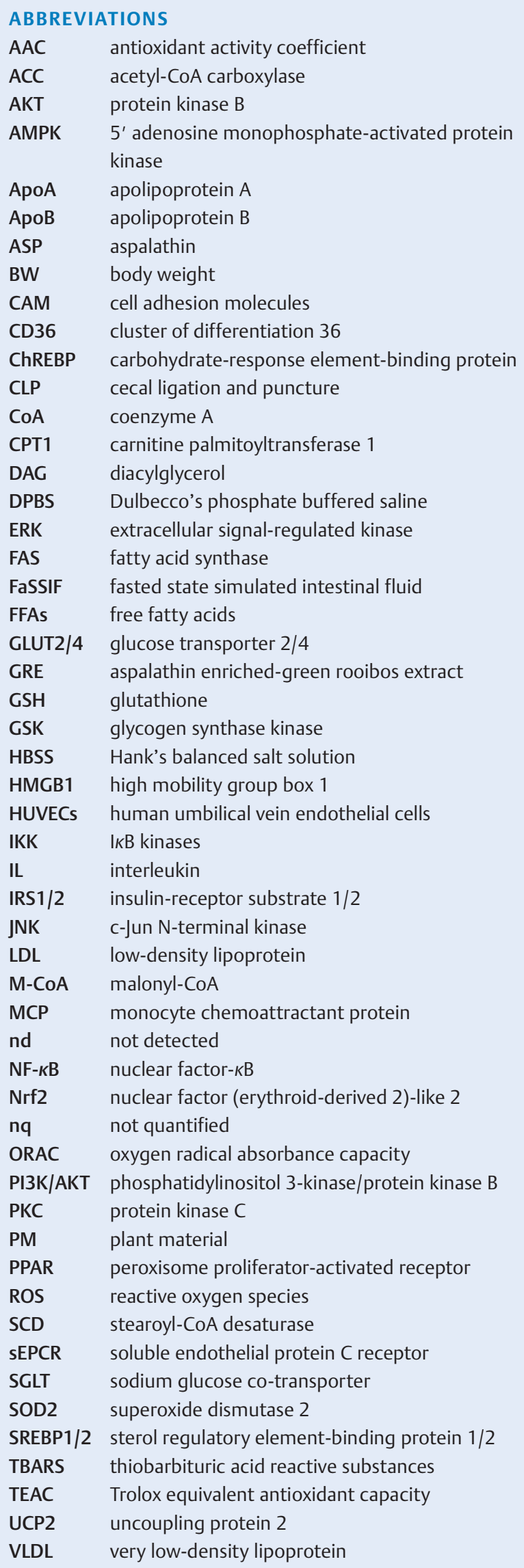

viewed by Idris and Donelly [3], Jesus et al. [4], and Blaschek [5]). In silico modelling of the natural C-glucosyl dihydrochalcone aspalathin ( $\triangleright$ Table 1 ) predicts that it may exhibit antidiabetic effects through inhibition of SGLT2 [6]. The present review provides a short discussion of the link between metabolic syndrome and, respectively, glucose metabolism, lipid metabolism, oxidative stress, and inflammation, as a background to a discussion of the potential of aspalathin in this context. Various in vitro and in vivo studies on aspalathin are highlighted, demonstrating its potential to target underlying metabolic dysfunction relative to the development or progression of serious metabolic diseases such as obesity, type 2 diabetes, and cardiovascular diseases. Studies describing the relevant biological activity of extracts prepared from green rooibos, containing high levels of aspalathin, are included to indicate potential mechanisms of action and provide perspective on the use of an aspalathin-rich extract versus pure compound. Other aspects of aspalathin covered in this review are its natural source, the variation in content and the impact of processing the plant material, physical and chemical properties, chemical synthesis, bioavailability, and potential interference with the metabolism of hypoglycaemic and hypocholesterolaemic drugs. To achieve this, the authors independently and systematically searched major databases, including PubMed, EMBASE, and Google Scholar, for available studies reporting on the chemical and physical properties of aspalathin, its bioavailability profile, as well as its ameliorative potential against various metabolic complications. The systematic search was conducted without any language restrictions, while unpublished and ongoing studies, in addition to review articles, were screened for primary findings.

\section{Natural source}

A recent review of the health effects of phloretin, the aglycone of phloridzin, stated that to date, about 200 dihydrochalcones, isolated from more than 300 plant families, have been identified [12]. Aspalathus linearis (Burm.f.) Dahlg., one of more than 270 species of the genus Aspalathus (Family Fabaceae, Tribe Crotalarieae) and endemic to the Cape Floristic Region $[13,14]$, is the natural and, until recently, only reported source of aspalathin. A closely related species, Aspalathus pendula R. Dahlgren, was recently also shown to contain aspalathin [15]. A. linearis is an erect to spreading shrub up to $2 \mathrm{~m}$ high with green, needle-like leaves on straight, slender branches. The leaves (15-60 mm long; up to $1 \mathrm{~mm}$ thick) are densely clustered without stalks and stipules. The small, yellow flowers of the cultivated type appear in spring to early summer and are solitary or arranged in groups at the tips of branches. The fruit is a small lance-shaped pod usually containing one or two hard seeds. The species is exceptionally polymorphic with ecotypes differing in morphology, fire survival strategy (reseeding or resprouting), geographical distribution, and phenolic composition [16-19]. Van Heerden et al. [19], investigating the phenolic profile of ecotypes of $A$. linearis, as well as that of the closely related $A$. pendula, did not detect aspalathin in the collected $A$. pendula samples, but demonstrated it to be the major compound in most $A$. linearis populations, including the cultivated type. Recently, however, Stander et al. [15], using state-of-the-art mass spectrometric techniques, could detect aspalathin in two populations of $A$. pendula. They concluded that $A$. linearis and 
- Table 1 Physical properties of aspalathin.

\begin{tabular}{|c|c|c|}
\hline Property (units) & Value & Reference \\
\hline \multicolumn{3}{|l|}{ Structure } \\
\hline IUPAC name & $\begin{array}{l}\text { 3-(3,4-Dihydroxyphenyl)-1-(2,4,6-trihydroxy-3-[(2S,3R,4R,5S,6R)-3,4,5-tri- } \\
\text { hydroxy-6-(hydroxymethyl)tetrahydro-2H-pyran-2-yl]phenyl)propan-1-one }\end{array}$ & [7] \\
\hline Molecular formula & $\mathrm{C}_{21} \mathrm{H}_{24} \mathrm{O}_{11}$ & {$[7,8]$} \\
\hline Molecular weight & 452.412 & {$[7,8]$} \\
\hline Melting point & $152-154^{\circ} \mathrm{C}$ & [9] \\
\hline Polar surface area $\left(\AA^{2}\right)$ & 208 & [7] \\
\hline Log P (predicted) & 2.07 & [8] \\
\hline Log D (pH 7.4) (experimental) & 0.13 & [10] \\
\hline $\log \mathrm{D}$ (pH 5.5) (experimental) & -0.347 & [11] \\
\hline $\mathrm{H}$ bond acceptors & 11 & {$[7,8]$} \\
\hline $\mathrm{H}$ bond donors & 9 & {$[7,8]$} \\
\hline Freely rotating bonds & 6 & {$[7,8]$} \\
\hline "Rule of 5" violations & 2 & [8] \\
\hline Solubility at $\mathrm{pH} 2(\mu \mathrm{M})$ & 153 & [10] \\
\hline Solubility at pH $6.5(\mu \mathrm{M})$ & 123 & [10] \\
\hline Solubility in FaSSIF at pH $6.5(\mu \mathrm{M})$ & 119 & {$[10]$} \\
\hline
\end{tabular}

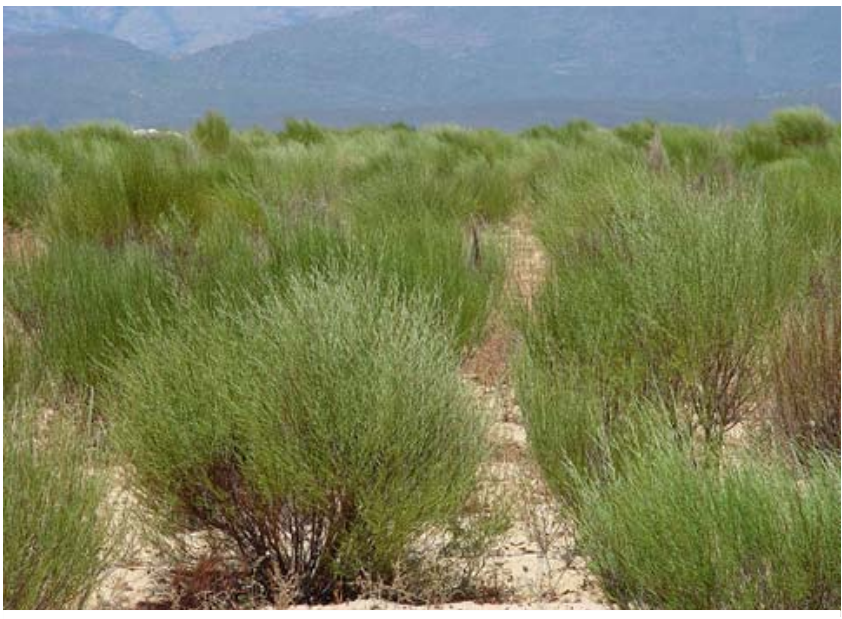

- Fig. 1 Commercial plantation of cultivated A. linearis (rooibos).

A. pendula produce similar combinations of main compounds with no diagnostic patterns. Only the selected and improved Nortier type (one of the Red Rocklands types) is used for commercial cultivation of rooibos tea ( $\vee$ Fig. $\mathbf{1}$ ) in the Cederberg region of the Western Cape.

The aspalathin content of the plant material is known to vary substantially between plants from the same plantation [20,21] due to the fact that the plants are propagated from open-pollinated seeds [22]. - Fig. 2 depicts the variation in the aspalathin content of the leaves of individual plants, harvested on the same

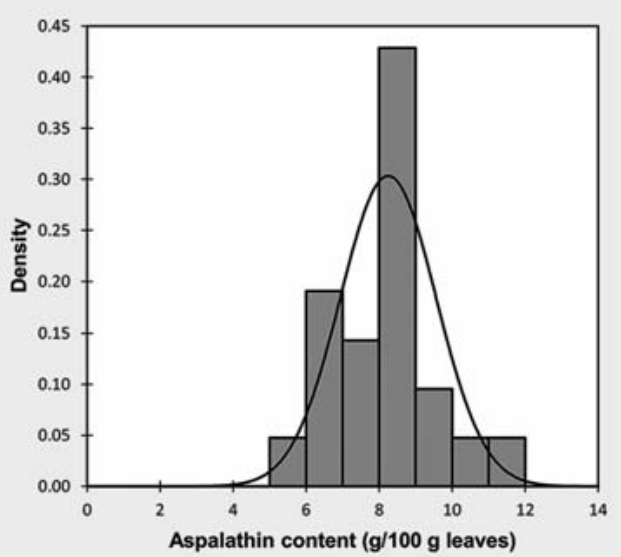

- Fig. 2 Normal distribution plots depicting the distribution of aspalathin content ( $\mathrm{g} / 100 \mathrm{~g}$ PM) of leaves from 21 individual A. linearis plants harvested on the same date from the same plantation (unpublished data; HPLC analysis as described in De Beer et al. [30]).

date from the same plantation. The largest number of leaf samples contained ca. $8 \%$ aspalathin (dry weight basis). $~$ Table 2 summarises ranges and means for aspalathin content in various types of plant material, extracts, and infusions. Aspalathin is present in substantially higher amounts in the leaves (6-13\%) [21] than the stems (0.16-0.78\%) ( $\triangleright$ Fig. 3) and thus also the whole dried shoots (4-10\%) [20]. Rooibos produced in the tradi- 
- Table 2 Aspalathin content and variation in various types of plant material (PM), extracts, and infusions.

\begin{tabular}{|c|c|c|c|c|}
\hline Sample type & $\mathbf{N}$ & Range (mean) & Units & Reference \\
\hline Dried leaves & 54 & $6.0-13.5(9.7)$ & $\mathrm{g} / 100 \mathrm{~g} P M$ & [21] \\
\hline Stems & 6 & $0.16-0.78(0.33)$ & $\mathrm{g} / 100 \mathrm{~g} P M$ & > Fig. 3 \\
\hline Whole dried shoots & 97 & $3.8-9.7(6.6)$ & $\mathrm{g} / 100 \mathrm{~g} P M$ & [20] \\
\hline Green product & 47 & $2.5-4.5(3.6)$ & $\mathrm{g} / 100 \mathrm{~g} P M$ & [25] \\
\hline Fermented product & 89 & $0.02-1.2(0.3)$ & $\mathrm{g} / 100 \mathrm{~g} P M$ & [20] \\
\hline Green hot water extract & 47 & $8.1-12.3(10.5)$ & $\mathrm{g} / 100 \mathrm{~g}$ extract & [25] \\
\hline Fermented hot water extract & 74 & $0.16-1.52(0.58)$ & $\mathrm{g} / 100 \mathrm{~g}$ extract & [26] \\
\hline Green infusion & 10 & $78-251(158)$ & $\mathrm{mg} / \mathrm{L}$ & [28] \\
\hline Fermented infusion & 114 & nd-15.7 (5.8) & $\mathrm{mg} / \mathrm{L}$ & [29] \\
\hline
\end{tabular}

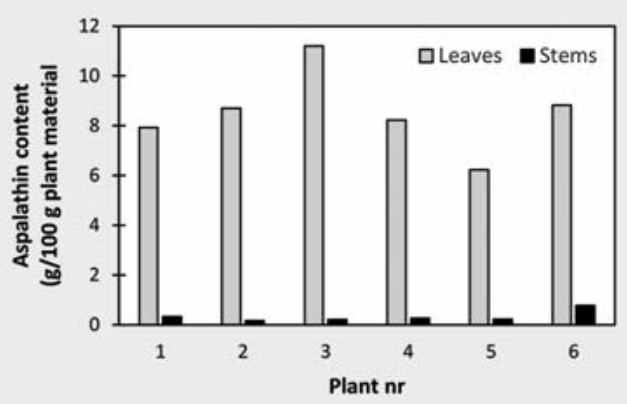

- Fig. 3 Aspalathin content ( $\mathrm{g} / 100 \mathrm{~g} \mathrm{PM}$ ) of leaves and stems of six individual $A$. linearis plants (unpublished data; HPLC analysis as described in De Beer et al. [30]).

tional manner that includes the "fermentation" (oxidation) step for development of the characteristic red-brown leaf colour and "woody", "fynbos-floral", and "honey" flavour [23, 24], and contains very little aspalathin (0.02-1.2\%) [20], while the "unfermented product", green rooibos, has an aspalathin content between 2.5 and $4.5 \%$ [25]. Hot water extracts prepared from fermented and green rooibos are used as food and/or cosmetic ingredients. If a high aspalathin content is required, a hot water extract (aspalathin content $>8 \%$ ) of green rooibos [25] is preferable. On the other hand, a hot water extract (aspalathin content $<2 \%$ ) of fermented rooibos [26] is more economical to produce and it is preferred in food products, such as rooibos iced tea, when the flavour is important [27]. Similarly, green rooibos infusions at "cupof-tea" strength have a much higher aspalathin content (78$251 \mathrm{mg} / \mathrm{L}$ ) [28] than fermented rooibos infusions (not detected$16 \mathrm{mg} / \mathrm{L}$ ) [29]. The bulk of rooibos production is processed to supply the demand for the traditional "fermented" herbal tea product [22].

\section{Quantification of aspalathin}

Several HPLC methods, based on UV-Vis detection, have been published through the years since the first HPLC method was developed to quantify the change in aspalathin content of the plant material with fermentation [31]. The need to quantify the phe- nolic content of a cup of fermented rooibos tea and extracts used in biological studies resulted in the development of a variety of methods [32-36]. The method developed by Beelders et al. [34] to characterise the phenolic content of infusions of fermented rooibos could, besides aspalathin, quantify the content of the dihydrochalcone nothofagin, the phenolic acid ferulic acid, and (Z)2-( $\beta$-D-glucopyranosyloxy)-3-phenylpropenoic acid, an enolic glucoside of phenylpyruvic acid, as well as the major flavones and flavonols. Quantitative data for rutin and quercetin-3-O-robinobioside indicate that these compounds most likely co-eluted when using previous methods. Comprehensive analysis of the phenolic composition of fermented rooibos are problematic since a number of critical peak pairs need to be resolved. The most recent method was shown to be suitable for quantification of the flavanone oxidation products of aspalathin [37]. A need to screen large numbers of green rooibos samples led to the development of a rapid HPLC method to quantify aspalathin, nothofagin, isoorientin, and orientin [30]. Kazuno et al. [38] used a triple quadrupole MS detector in a selected reaction monitoring mode to quantify a number of rooibos phenolic compounds, including aspalathin. The use of mass spectrometric detection increases the sensitivity and specificity of the method. The suitability of capillary zone electrophoresis for quantification of aspalathin and other phenolic compounds in rooibos was investigated by Arries et al. [39]. It was deemed less sensitive and a smaller number of compounds could be quantified with suitable reproducibility, but has potential as a rapid, inexpensive alternative method, especially for quantification of the major compounds.

\section{Physical and chemical properties}

Aspalathin (PubChem CID: 11282394; Chemspider ID: 9457391) is a natural $C$-glucosyl dihydrochalcone ( $3^{\prime}-\beta$-D-glucopyranosyl$2^{\prime}, 3,4,4^{\prime}, 6^{\prime}$-pentahydroxydihydrochalcone) with the molecular formula $\mathrm{C}_{21} \mathrm{H}_{24} \mathrm{O}_{11}$ (MW $452.412 \mathrm{~g} / \mathrm{mol}$ ) ( Table 1) [7,8]. The compound was first described by Koeppen $[40,41]$, originally designated "compound J", and tentatively identified as a flavanone based on its chromatographic properties, chromogenic reactions with a variety of reagents, UV-Vis and infrared spectra, spectral shifts, and hydrolysis products. Aspalathin was eventually identified as a dihydrochalcone based on its oxidation products [9] and NMR data acquired at $60 \mathrm{MHz}$ [42]. Renewed interest in the phe- 


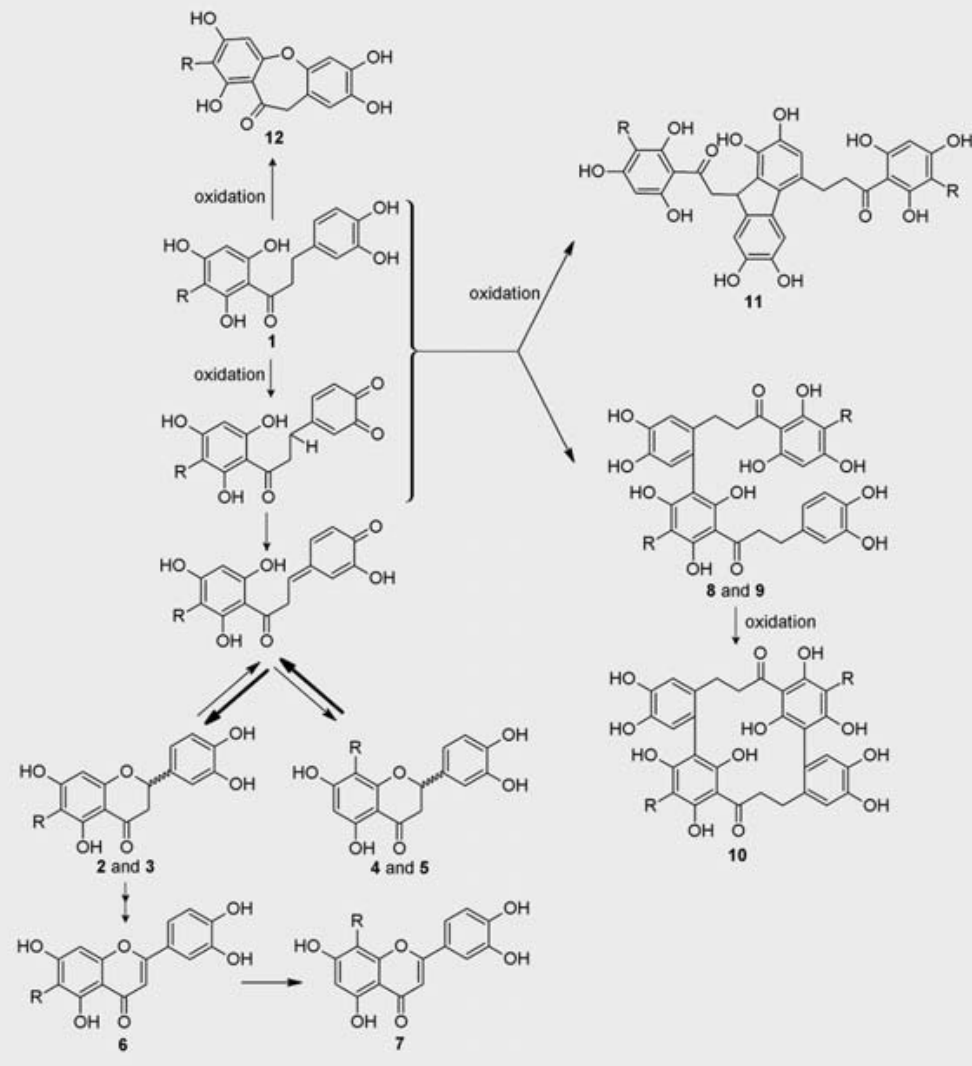

- Fig. 4 Oxidation of aspalathin in the presence of oxygen. [1, aspalathin; 2, (S)-6- $\beta$-D-glucopyranosyleriodictyol; 3, (R)-6- $\beta$-D-glucopyranosyleriodictyol; 4, (S)-8- $\beta$-D-glucopyranosyleriodictyol; 5, (R)-8- $\beta$-D-glucopyranosyleriodictyol; 6, isoorientin; 7, orientin; 8, 9, 10, 11, aspalathin dimers; $\mathrm{R}=\beta$-D-glucopyranosyl]. Compiled from previous reports [45-47].

nolic composition of rooibos more than 30 years after the first isolation of aspalathin resulted in full elucidation of its structure via ${ }^{1} \mathrm{H}$ NMR data acquired at $300 \mathrm{MHz}$ [43].

Aspalathin is readily soluble in water and polar solvents, but insoluble in nonpolar solvents. Other physical properties, relating specifically to bioavailability, are discussed later. It is highly susceptible to oxidation in the presence of oxygen in solution [ 30 , 42,44-47] and rooibos plant material [31]. In the latter matrix, enzymes catalyse the reaction (unpublished data). Bruising of the fresh leaves results in rapid browning. The oxidation products identified in solution are shown in $>$ Fig. 4. Oxidation commences by cyclisation of aspalathin (1) to form the diastereomeric flavanone mixture (S)- and (R)-6- $\beta$-D-glucopyranosyleriodictyol ( 2 and 3 ) as major products and the diastereomeric mixture $(S)$ - and $(R)$ 8 - $\beta$-D-glucopyranosyleriodictyol ( 4 and 5 ) as minor products. The flavanones 2 and 3 are oxidised to form the flavone isoorientin (6). The latter compound is susceptible to a Wessely-Moser-type rearrangement, i.e., hydrolysis of the enolic ether functionality and subsequent recyclisation of a 1,3-diketo intermediate via the alternative o-hydroxy group, to form orientin (7) irreversibly, although the major oxidation products are unidentified brown material. The flavanones 4 and 5 are not oxidised directly to orientin (7), but these compounds are postulated to be reversibly transformed into the thermodynamically more stable flavanones 2 and 3 via the intermediate quinone methide. Further oxidation products of aspalathin include 8 and 9 atropo-diastereomeric phenols formed via phenol oxidative A- to B-ring coupling. These dimers can undergo a second phenol oxidative coupling to form the dimer $\mathbf{1 0}$. The $9 \mathrm{H}$-fluorene $\mathbf{1 1}$ is postulated to form via a two-step oxidation process. The dimers are also susceptible to further oxidation into unidentified brown products. A study to investigate the formation of the brown colour upon oxidation identified aspalathin as the most important substrate for the formation of coloured products [47].

Degradation of aspalathin is $\mathrm{pH}$ dependent ( $\bullet$ Fig. 5). Aspalathin stability is highest at a low $\mathrm{pH}$ and substantial degradation (47\%) occurs over $24 \mathrm{~h}$ at $\mathrm{pH} 7$ in a citric acid-phosphate buffer at room temperature ( $\vee$ Fig. 5A) [30]. Other factors such as buffer type, ascorbic acid, and environment also have an effect ( $\vee$ Fig. 5B,C; unpublished results). A phosphate buffer ( $\mathrm{pH} 7.4$ ) without citric acid showed up to $97 \%$ degradation over $24 \mathrm{~h}$ at room temperature ( $\vee$ Fig. 5 B), indicating that citric acid has a protective effect. The metal chelating properties of citric acid may be a contributing factor. Ascorbic acid, on the other hand, was able to completely prevent aspalathin degradation in a phosphate buffer ( $\mathrm{pH} 7.4$ ) over $24 \mathrm{~h}$ at room temperature ( $\bullet$ Fig. 5 B). 

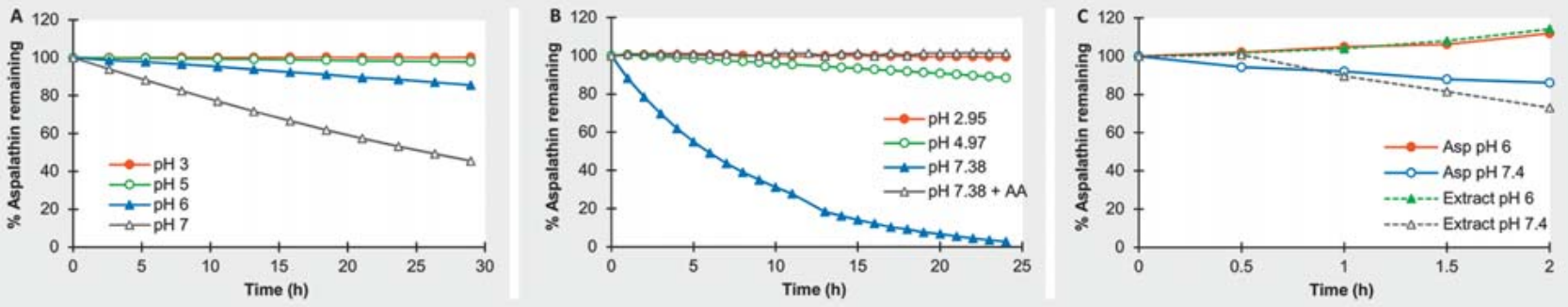

- Fig. 5 Effect of pH on stability of pure aspalathin (ASP) and when present in green rooibos extract. Conditions were as follows: A citric acidphosphate buffer at room temperature (adapted from De Beer et al. [30]); B phosphate buffered saline at room temperature (AA=1\% ascorbic acid) (unpublished data; HPLC analysis as described in joubert et al. [48]); $\mathrm{C}$ HBSS under cell culture conditions $\left(37^{\circ} \mathrm{C}, 5 \% \mathrm{CO}_{2}, 95 \%\right.$ humidity) (unpublished data; HPLC analysis as described in Bowles et al. [10]).

For a study on the permeability of aspalathin in a Caco-2 cell model [10], the stability of aspalathin as a pure compound and when present in an aspalathin-rich green rooibos extract was determined under cell culture conditions $(\mathrm{pH} 7.4)$ over $2 \mathrm{~h}$ in HBSS ( $\vee$ Fig. 5C). Under these conditions, 14 and 27\% degradation of the compound occurred when pure aspalathin and aspalathin-rich extract, respectively, were tested. At pH 6 under cell culture conditions, the aspalathin concentration slightly increased, which was attributed to evaporation of the medium.

\section{Antioxidant and pro-oxidant properties}

Research interest in natural phenolic antioxidants began to escalate from 1995 as evidenced by the increase in the number of papers published [49]. Prior to this date, Japanese interest in rooibos produced a few papers relating to the free radical scavenging ability of fermented rooibos (as reviewed by Joubert et al. [50]). The latter research led to the association of rooibos with "anti-ageing" properties [22]. These findings, together with the demonstration of high aspalathin levels in the "unfermented" plant material and the susceptibility of aspalathin to oxidation [31], prompted research into the antioxidant properties of aspalathin. This research focussed at first on aspalathin as a potential replacement for synthetic antioxidants in food, but later the focus shifted to its potential role as an exogenous antioxidant, due to the hypothesis that phenolic antioxidants in the diet could assist in maintaining redox homeostasis in the cell gaining traction [51].

The in vitro antioxidant activity of aspalathin ( $\vee$ Table 3 ) has been assessed in a variety of assays including radical scavenging and lipid peroxidation assays [52-56]. Aspalathin generally had lower antioxidant activity than the well-known radical scavenger quercetin $[52,54,55,57]$, although similar activity was reported in the ABTS radical cation [54,56], Fremy's radical [56] and superoxide radical anion [52] scavenging assays. Aspalathin also showed pro-oxidant activity in the deoxyribose assay [53]. In this assay, hydroxy radicals are generated in a Fenton reaction model system containing $\mathrm{FeCl}_{3}$-EDTA and $\mathrm{H}_{2} \mathrm{O}_{2}$, where aspalathin was able to reduce $\mathrm{Fe}^{3+}$ to $\mathrm{Fe}^{2+}$, thereby increasing formation of hydroxy radicals. In this system, potent antioxidants act as potent pro-oxidants. In a recent paper, the dual antioxidant and/or prooxidant role of rooibos polyphenol constituents, in particular as- palathin, was postulated to play a role in the prevention of UVBinduced skin carcinogenesis [58]. With regard to lipid peroxidation, the activity of aspalathin was compared to that of isoquercitrin, a quercetin glucoside, in the Rancimat and LDL oxidation assays. Aspalathin showed higher and lower inhibitory activity than isoquercitrin in these assays, respectively. In the $\beta$-carotene bleaching and $\mathrm{Fe}(\mathrm{II})$-induced microsomal lipid peroxidation assays, aspalathin showed lower activity than quercetin $[54,55]$. The Fe(II)-induced microsomal lipid peroxidation assay was chosen as a model for oxidation in a membrane system. For better comprehension of its interaction with the membrane to protect against oxidation, in particular, in comparison to its 3-deoxy and co-occurring analogue, nothofagin, the minimum energy conformations of these dihydrochalcones were considered to explain their relative affinity to interact with the membrane [54]. According to their most likely conformers, aspalathin would have a more "open" structure, postulated to improve accessibility of its catechol group to interact with the polar heads of the lipid bilayers for radical scavenging at the membrane interphase [54]. Aspalathin shares the 2',6'-dihydroxyacetophenone antioxidant pharmacophore with phloretin [59]. The oxidation products of aspalathin, namely (S)- and (R)-6- $\beta$-D-glucopyranosyleriodictyol, isoorientin and orientin, generally had lower antioxidant activity than aspalathin $[52,54,56]$. The two exceptions are that aspalathin and orientin showed similar DPPH radical scavenging activity [52], while isoorientin and orientin showed higher activity than aspalathin in the ORAC assay [57].

\section{Chemical and potential biocatalytic syntheses}

The emphasis to obtain a process for chemical synthesis of aspalathin stems from its relatively low content in the bulk of rooibos produced (i.e., fermented rooibos tea), the cost and challenge of isolation from the plant material, and the limited supply of plant material, especially green rooibos. Synthesis of aspalathin would represent a sustainable option if economically feasible. An eightstep process using tri-O-benzylglucal, tri-O-benzylphloroglucinol, and 3,4-bis(benzyloxy)phenylacetylene as starting materials was reported by Yepremyan et al. [60]. This process involved a stereoselective Lewis acid-promoted coupling of 1,2-di-O-acyl-3,4,6-tri$O$-benzylglucose with tri-O-benzylphloroglucinol, leading to the 
- Table 3 Summary of in vitro antioxidant and pro-oxidant activity of aspalathin.

\begin{tabular}{|c|c|c|c|c|}
\hline Assay & $\begin{array}{l}\text { Antioxidant } \\
\text { mechanism }\end{array}$ & $\begin{array}{l}\text { Antioxidant } \\
\text { measure }\end{array}$ & Relative activity & $\begin{array}{l}\text { Refer- } \\
\text { ence }\end{array}$ \\
\hline $\begin{array}{l}\text { DPPH radical } \\
\text { scavenging }\end{array}$ & $\begin{array}{l}\text { Synthetic radical } \\
\text { scavenging }\end{array}$ & \% Inhibition & $\begin{array}{l}\text { Higher activity than BHT, BHA, } \alpha \text {-tocopherol, luteolin, vitexin, rutin, and phenolic } \\
\text { acids } \\
\text { Lower activity than quercetin, catechin, and isoquercitrin }\end{array}$ & [55] \\
\hline $\begin{array}{l}\text { DPPH radical } \\
\text { scavenging }\end{array}$ & $\begin{array}{l}\text { Synthetic radical } \\
\text { scavenging }\end{array}$ & \% Inhibition & $\begin{array}{l}\text { Higher activity than isoorientin, catechin, epicatechin, rutin, Trolox, vitexin, } \\
\text { and chrysoeriol } \\
\text { Similar activity to orientin, luteolin, isoquercitrin, and propyl gallate } \\
\text { Lower activity than quercetin and procyanidin B1, B2, B3, and B4 }\end{array}$ & [52] \\
\hline $\begin{array}{l}\text { ABTS radical } \\
\text { cation scaveng- } \\
\text { ing }\end{array}$ & $\begin{array}{l}\text { Synthetic radical } \\
\text { scavenging }\end{array}$ & $\mathrm{IC}_{50}$ & $\begin{array}{l}\text { Higher activity than Trolox, catechin, orientin, isoorientin, luteolin, chrysoeriol, } \\
\text { rutin, isoquercitrin, hyperoside, nothofagin, vitexin, and isovitexin } \\
\text { Similar activity to quercetin and epigallocatechin gallate }\end{array}$ & {$[54]$} \\
\hline $\begin{array}{l}\text { ABTS radical } \\
\text { cation scaveng- } \\
\text { ing }\end{array}$ & $\begin{array}{l}\text { Synthetic radical } \\
\text { scavenging }\end{array}$ & TEAC & $\begin{array}{l}\text { Higher activity than nothofagin, isoorientin, orientin, isovitexin, vitexin, (S)- and } \\
(R)-6-\beta \text {-D-glucopyranosyleriodictyol, rutin, isoquercitrin, and hyperoside } \\
\text { Similar activity to quercetin }\end{array}$ & {$[56]$} \\
\hline $\begin{array}{l}\text { Fremy's radical } \\
\text { scavenging }\end{array}$ & $\begin{array}{l}\text { Synthetic radical } \\
\text { scavenging }\end{array}$ & $\begin{array}{l}\text { Mole radicals } \\
\text { scavenged per } \\
\text { mole compound }\end{array}$ & $\begin{array}{l}\text { Higher activity than nothofagin, isoorientin, orientin, isovitexin, vitexin, (S)- and } \\
(R)-6-\beta \text {-D-glucopyranosyleriodictyol, rutin, isoquercitrin, and hyperoside } \\
\text { Similar activity to quercetin }\end{array}$ & {$[56]$} \\
\hline $\begin{array}{l}\text { Superoxide } \\
\text { radical scaveng- } \\
\text { ing }\end{array}$ & $\begin{array}{l}\text { Oxygen radical } \\
\text { scavenging }\end{array}$ & \% Inhibition & $\begin{array}{l}\text { Higher activity than orientin, luteolin, isoquercitrin, isoorientin, catechin, } \\
\text { epicatechin, rutin, Trolox, vitexin, and chrysoeriol } \\
\text { Similar activity to quercetin } \\
\text { Lower activity than propyl gallate and procyanidin B1, B2, B3, and B4 }\end{array}$ & {$[52]$} \\
\hline $\begin{array}{l}\text { ORAC with } \\
\text { fluorescein }\end{array}$ & $\begin{array}{l}\text { Peroxyl radical } \\
\text { scavenging }\end{array}$ & ORAC index & $\begin{array}{l}\text { Higher activity than nothofagin } \\
\text { Lower activity than quercetin, orientin, isoorientin, vitexin, isoquercitrin, } \\
\text { and hyperoside }\end{array}$ & [57] \\
\hline $\begin{array}{l}\text { ORAC with } \\
\text { pyrogallol red }\end{array}$ & $\begin{array}{l}\text { Peroxyl radical } \\
\text { scavenging }\end{array}$ & ORAC index & $\begin{array}{l}\text { Higher activity than nothofagin, orientin, isoorientin, vitexin, isoquercitrin, } \\
\text { and hyperoside } \\
\text { Lower activity than quercetin }\end{array}$ & [57] \\
\hline $\begin{array}{l}\text { Deoxyribose } \\
\text { degradation in } \\
\text { Fenton system }\end{array}$ & $\begin{array}{l}\text { Hydroxyl radical } \\
\text { scavenging/ } \\
\text { generation }\end{array}$ & $\begin{array}{l}\text { TBARS vs. } \\
\text { control }\end{array}$ & Pro-oxidant activity in the absence of ascorbic acid & [53] \\
\hline $\begin{array}{l}\text { Rancimat lard } \\
\text { oxidation }\end{array}$ & $\begin{array}{l}\text { Lipid peroxida- } \\
\text { tion }\end{array}$ & Induction period & $\begin{array}{l}\text { Higher activity than } p \text {-hydroxybenzoic acid, ferulic acid, and p-coumaric acid } \\
\text { Lower activity than quercetin, BHT, } \alpha \text {-tocopherol, catechin, luteolin, rutin, iso- } \\
\text { quercitrin, caffeic acid, and protocatechuic acid }\end{array}$ & {$[55]$} \\
\hline $\begin{array}{l}\text { Coupled } \beta \text {-caro- } \\
\text { tene bleaching } \\
\text { and linoleic acid } \\
\text { oxidation }\end{array}$ & $\begin{array}{l}\text { Lipid peroxida- } \\
\text { tion }\end{array}$ & $\begin{array}{l}\text { AAC after } \\
120 \text { min reac- } \\
\text { tion time }\end{array}$ & $\begin{array}{l}\text { Higher activity than catechin, vitexin, rutin, isoquercitrin, and phenolic acids } \\
\text { Lower activity than quercetin, BHT, BHA, } \alpha \text {-tocopherol, and luteolin }\end{array}$ & {$[55]$} \\
\hline LDL oxidation & $\begin{array}{l}\text { Lipid peroxida- } \\
\text { tion }\end{array}$ & Lag time & $\begin{array}{l}\text { Higher activity than isoorientin, orientin, nothofagin, and (S)-6- } \beta \text {-D-glucopyra- } \\
\text { nosyleriodictyol } \\
\text { Lower activity than isoquercitrin }\end{array}$ & {$[56]$} \\
\hline $\begin{array}{l}\text { Fe(II)-induced } \\
\text { microsomal lipid } \\
\text { peroxidation }\end{array}$ & $\begin{array}{l}\text { Lipid peroxida- } \\
\text { tion }\end{array}$ & $\mathrm{IC}_{50}$ & $\begin{array}{l}\text { Higher activity than Trolox, orientin, isoorientin, luteolin, chrysoeriol, rutin, } \\
\text { isoquercitrin, hyperoside, nothofagin, vitexin, and isovitexin } \\
\text { Similar activity to catechin } \\
\text { Lower activity than quercetin and epigallocatechin gallate }\end{array}$ & {$[54]$} \\
\hline
\end{tabular}

corresponding $\beta$-D-glucopyranosylphloroglucinol derivative that was subsequently transformed to aspalathin. Nothofagin was also synthesised in a similar manner. Since the aforementioned synthetic protocol resulted in a low yield (20\%), an alternative sequence was developed by Van der Westhuizen and coworkers ( $\vee$ Fig. 6) [61]. Glucosylation of the di-O-benzylacetophenone 14 with the $\alpha$-fluoroglucosyl derivative 13 under Lewis acid-catalysis afforded the $\alpha$-glucopyranosyloxy analogue 15 in an $86 \%$ yield. Increasing the temperature from -40 to $-15^{\circ} \mathrm{C}$ permitted a facile $\mathrm{BF}_{3}$-catalysed rearrangement to the $\beta$-glucopyranosyl derivative
16 in an 84\% yield. Aldol condensation of 16 with 3,4-dibenzyloxybenzaldehyde 17 afforded the protected chalcone 18 (96\% yield), which upon hydrogenation gave aspalathin in an $80 \%$ overall yield. Based on the excellent overall yield and its scalability potential, the process was subsequently patented [62]. Recently, a number of C-glycosyl chalcone analogues of aspalathin were synthesised by a simple three-step process [63]. These analogues displayed good DPPH radical scavenging activity and inhibited proliferation of liver and breast cancer cells. 

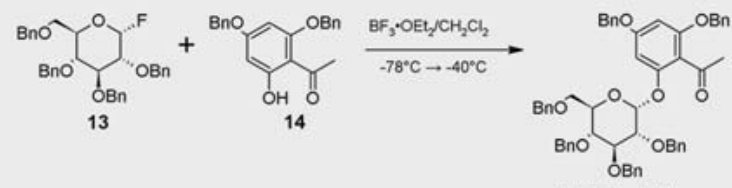

15 ( $86 \%$ yield)

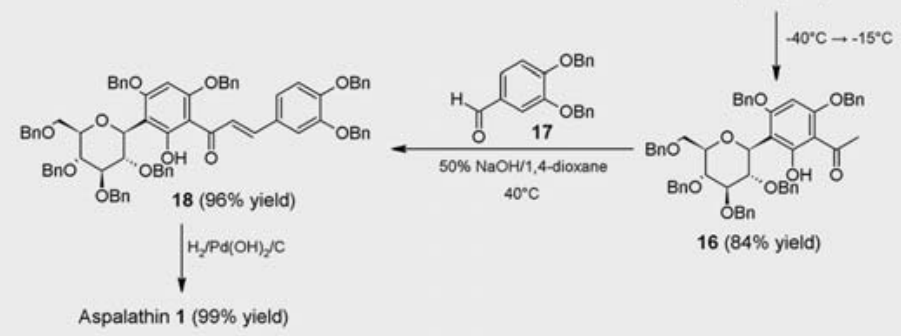

- Fig. 6 Four-step synthesis of aspalathin. Adapted from Han et al. [61].

Another possibility for the synthesis of aspalathin may be the biotransformation by enzymatic C-glycosylation of the aglycone, as was achieved for nothofagin [64,65]. A C-glycosyltransferase from rice, which was perfectly selective, was used to glucosylate phloretin using uridine diphosphate-glucose, giving an $80 \%$ yield of nothofagin [64]. In further work, the same group increased the efficiency of conversion by complexing phloretin with $\beta$-cyclodextrin to improve its solubility [65].

De novo synthesis of nothofagin and a number of other related dihydrochalcones was recently accomplished using metabolically engineered Saccharomyces cerevisiae [66]. This was done by expressing the full-length biosynthetic pathways, consisting of between four and nine genes, in the microbial host. Although the authors note that the process is not yet economically viable, metabolically engineered microbes have great potential for targeted sustainable production of high-value phenolic compounds such as aspalathin.

\section{Bioavailability}

Aspalathin, normally ingested by drinking rooibos or consuming food supplemented with rooibos extract, requires absorption through the gut into the blood stream to reach the systemic site of action in adequate concentrations to be bioefficient, apart from its beneficial gastrointestinal luminal effects. Considering that various physical properties of aspalathin ( $\vee$ Table 2 ) related to membrane permeability fail to meet various criteria, limited absorption is to be expected. Whilst its molecular weight and log $P$ value do not exceed the limits of 500 and 5, respectively, the number of $\mathrm{H}$-bond donors and acceptors violate Lipinski's "Rule of 5" [67]. The hydrophilic nature of aspalathin not only indicates poor permeability for gastrointestinal penetration, but also susceptibility to renal clearance [68]. Additionally, the polar surface area of aspalathin exceeds $140 \AA^{2}$, indicating a high probability of poor oral bioavailability [69].

Low membrane permeability of aspalathin has been reported in Caco-2 monolayer cell model studies. Relevant details of these studies are summarised in > Table 4. Notably, Huang et al. [11] found that aspalathin absorption increased when present in green rooibos extract as opposed to the pure compound, indicating that other plant components present in the extract may assist in its transport across the membrane. In contrast, Bowles et al. [10] found absorption of pure aspalathin to be similar to that when present in green rooibos extract. Experimental differences may account for this disparity in results, in particular the substantially higher aspalathin concentration, as well as the higher permeability of the monolayer used by Huang et al. [11]. Courts and Williamson [70] postulated that the passive diffusion of aspalathin is most likely responsible for its absorption across the intestinal epithelial monolayer. Insight into the mechanism of aspalathin transport, using the Caco-2 monolayer cell model, was gained from the study by Bowles et al. [10]. Following inhibition of aspalathin transport in the presence of a high glucose concentration (20.5 mM), the role of active glucose transporters such as SGLT1 and GLUT2 was investigated by performing experiments in the presence and absence of SGLT1 (phloridzin), GLUT2 (phloretin), and efflux $(\mathrm{Pg})$ (verapamil) inhibitors. No effect on aspalathin transport was observed, leading to the conclusion that aspalathin is transported paracellularly, especially given its physical characteristics. Transport of aspalathin across the intestinal epithelial monolayer occurred without evidence of deglucosylation [70] or formation of other metabolites [10].

In vitro phase II metabolism of aspalathin with microsomal and cytosolic subcellular rat liver fractions and added cofactors produced two glucuronidated and one sulphated metabolite [71]. Methylation of aspalathin was demonstrated when treated with human liver and intestinal cytosolic fractions, following the addition of the cofactor [72]. Conjugates of aspalathin with glucuronic acid, sulphate, a methyl group, or a combination were detected in animal and human urine $[10,33,36,72,73]$. Deglucosylation of aspalathin is thus not a prerequisite for its absorption. Traces of methyl conjugates were found in the plasma of Vervet monkeys after being fed a single bolus containing green rooibos extract delivering $25 \mathrm{mg}$ aspalathin per $\mathrm{kg}$ body weight [28]. Unconjugated aspalathin was detected in human plasma after ingesting a green rooibos beverage containing $287 \mathrm{mg}$ aspalathin ( $\triangleright$ Table 5). In all of the in vivo studies, except the mouse study, aspalathin was in- 
- Table 4 Rate of transport of aspalathin from buffered solutions of pure aspalathin and green rooibos extracts across the Caco-2 monolayer from apical to basolateral side.

\begin{tabular}{|c|c|c|c|c|}
\hline Treatment & Concentration $^{1}$ & $P_{\text {app }} \times 10^{-6}$ & \% Passage & Reference \\
\hline \multirow{3}{*}{$\begin{array}{l}\text { Green rooibos extract in DPBS with calcium and magnesium } \\
(\mathrm{pH} 7.4)\end{array}$} & $1 \mathrm{mg} / \mathrm{mL}(0.43 \mathrm{mM})$ & $4 \pm 0.42$ & & {$[11]$} \\
\hline & $5 \mathrm{mg} / \mathrm{mL}(2.15 \mathrm{mM})$ & $3.49 \pm 1.45$ & & \\
\hline & $10 \mathrm{mg} / \mathrm{mL}(4.29 \mathrm{mM})$ & $20.93 \pm 3.61$ & $\sim 100 \%$ & \\
\hline \multirow[t]{3}{*}{ Aspalathin in DPBS with calcium and magnesium ( $\mathrm{pH} 7.4)$} & $0.2 \mathrm{mg} / \mathrm{mL}(0.44 \mathrm{mM})$ & $0.91 \pm 0.37$ & & \\
\hline & $1 \mathrm{mg} / \mathrm{mL}(2.21 \mathrm{mM})$ & $2.48 \pm 0.03$ & & \\
\hline & $2 \mathrm{mg} / \mathrm{mL}(4.42 \mathrm{mM})$ & $15.34 \pm 1.66$ & $79 \%$ & \\
\hline \multirow[t]{2}{*}{ Aspalathin in HBSS (pH 6.0 $)^{2}$} & $1 \mu \mathrm{M}$ & $2.28 \pm 0.09$ & & {$[10]$} \\
\hline & $150 \mu \mathrm{M}$ & $1.73 \pm 0.97$ & $5 \%$ & \\
\hline Aspalathin in HBSS (with high glucose; 20.5 mM; pH 6.0) & $150 \mu \mathrm{M}$ & $0.29 \pm 0.08$ & $2 \%$ & \\
\hline Green rooibos extract in HBSS ( $\mathrm{pH} 6.0$ ) & $0.38 \mathrm{mg} / \mathrm{mL}(153 \mu \mathrm{M})$ & $2.00 \pm 1.10$ & & \\
\hline Enriched green rooibos fraction in HBSS ( $\mathrm{pH} 6.0$ ) & $0.15 \mathrm{mg} / \mathrm{mL}(149 \mu \mathrm{M})$ & $2.11 \pm 0.20$ & & \\
\hline
\end{tabular}

gested as part of a rooibos extract, either mixed into the feed of the animals or consumed as a rooibos beverage by human subjects ( $\vee$ Table 5 ). Major outcomes of these studies were that aspalathin metabolites reached maximum concentration in the plasma in $3 \mathrm{~h}$ or less [33] and that only a small quantity of the ingested amount was bioavailable $[33,36,72]$.

Of interest is the presence of the conjugated aspalathin aglycone, observed in mouse [10] and human [33] urine. The resistance of the $\mathrm{C}-\mathrm{C}$ bond to the action of lactase phloridzin hydrolase, present in the brush-border of the small intestinal epithelial cells, as well as the action of cytosolic $\beta$-glucosidase [74], requires liberation of the aglycone by colonic microflora. Human colonic bacteria able to hydrolyse the $\mathrm{C}-\mathrm{C}$ bond have been identified for a number of C-glucosyl compounds [75-77]. Eubacterium cellulosolvens, isolated from mice, are able to deglucosylate orientin and isoorientin [78]. Using oxidation products of aspalathin as a starting point and outcomes of studies on the anaerobic catabolism of these flavones, Muller et al. [28] proposed a microbial biotransformation pathway for aspalathin, ultimately leading to the formation of dihydrocaffeic acid and organic acids in the colon.

\section{Rising burden of metabolic syndrome and preventative potential of aspalathin}

The metabolic syndrome describes a cluster of metabolic anomalies that underlie the development of serious metabolic disease such as type 2 diabetes, obesity, and cardiovascular disease, contributing to the rising burden of noncommunicable diseases [79]. Perturbations of glucose and lipid metabolism as a result of insulin resistance play a major role in the development of the metabolic syndrome. Individuals with this condition exhibit multiple risk factors including elevated fasting plasma glucose, high serum triglycerides, and high blood pressure, which increase the probability of developing cardiovascular complications [80]. Urbanisation with accompanying lifestyle changes, namely, excessive energy intake and lack of physical activity, contributes to these metabolic diseases [79]. Current global estimates show that more than 2 billion children and adults are overweight or obese, whereas a total of 107.7 million children and 603.7 million adults were recorded to be obese in 2015 [81]. Furthermore, the International Diabetes Federation has reported that 415 million adults have diabetes at present and this number is expected to rise to 642 million by 2040 [82]. Cardiovascular diseases, major comorbidities of type 2 diabetes, greatly contribute to global mortality [79]. In addition to cardiovascular diseases, the metabolic syndrome increases the risk of organ damage to the liver (nonalcoholic fatty liver disease), muscle (muscle deterioration), and pancreas (pancreatic $\beta$-cell dysfunction) $[83,84]$. The generation of excessive oxidative stress, a consequence of depleted antioxidant systems due to the overproduction of ROS, and accelerated inflammation driven by elevated proinflammatory cytokine production, are both implicated in metabolic syndrome-induced organ damage [85]. Nevertheless, there is an increase in evidence that dietary interventions may reduce oxidative stress and inflammation associated with the metabolic syndrome, thereby decreasing cardiovascular risk [86, 87]. For example, antioxidant transcriptional factors such as $\mathrm{Nrf2}$, as well as its associated downstream target genes including those coding for $\mathrm{GSH}$, have emerged as essential targets in the amelioration of oxidative stress-induced cardiovascular and liver damage [88-90]. Similarly, effective modulation of protein kinases such as JNK, IKK, ERKs, and AMPK by certain natural products has been correlated with a reduced inflammatory response and cell damage [91-93]. Evidence demonstrating the ameliorative potential of aspalathin against the metabolic syndrome and its associated complications is attracting a lot of interest. The following sections provide a brief overview of the metabolic processes involved in altered glucose and lipid metabolism, leading to exacerbated oxidative stress and inflammatory-induced cell damage. A separate section deals specifically with the protective potential of aspalathin and its possible interference with the metabolism of hypoglycaemic and hypocholesterolaemic drugs. 
- Table 5 Summary of studies investigating oral bioavailability of aspalathin (ASP).

\begin{tabular}{|c|c|c|c|c|c|c|}
\hline Model & ASP dose & Dosage form & $\begin{array}{l}\text { ASP and metabo- } \\
\text { lites in plasma }\end{array}$ & ASP and metabolites in urine & $\begin{array}{l}\text { Excretion } \\
\text { in urine }\end{array}$ & $\begin{array}{l}\text { Refer- } \\
\text { ence }\end{array}$ \\
\hline Mouse & $\begin{array}{l}50 \mathrm{mg} / \mathrm{kg} \mathrm{BW} \text {, single } \\
\text { dose }\end{array}$ & $\begin{array}{l}\text { Pure ASP in PBS; } \\
\text { orogastric } \\
\text { gavage }\end{array}$ & nd & $\begin{array}{l}\text { sulphated ASP (4); glucuronidated } \\
\text { ASP (2); methylated ASP (2), methy- } \\
\text { lated and glucoronidated ASP (2), } \\
\text { methylated and sulphated ASP; } \\
\text { methylated and glucuronidated ASP } \\
\text { aglycone; a C-glucopyranosyl erio- } \\
\text { dictyol }\end{array}$ & nq & [10] \\
\hline Pig & $\begin{array}{l}\text { 157-167 mg/kg BW } \\
\text { daily for } 11 \text { days }\end{array}$ & $\begin{array}{l}\text { ASP-rich GR ex- } \\
\text { tract ( } 16.3 \%) \\
\text { mixed with feed }\end{array}$ & nd & $\begin{array}{l}\text { ASP; glucuronidated ASP; methylated } \\
\text { ASP; methylated and glucuronidated } \\
\text { ASP; glucuronidated ASP aglycone }\end{array}$ & 0.1 to $0.9 \%$ & [73] \\
\hline $\begin{array}{l}\text { Vervet } \\
\text { monkey }\end{array}$ & $\begin{array}{l}25 \mathrm{mg} / \mathrm{kg} \mathrm{BW} \text {, single } \\
\text { dose }\end{array}$ & $\begin{array}{l}\text { ASP-rich GR ex- } \\
\text { tract }(18.4 \%) \\
\text { mixed with bolus }\end{array}$ & $\begin{array}{l}\text { methylated ASP } \\
(2)\end{array}$ & Methylated ASP; dimethylated ASP & $\mathrm{nq}$ & $\begin{array}{l}\text { Unpub- } \\
\text { lished }\end{array}$ \\
\hline Human & $\begin{array}{l}91 \mathrm{mg} / \text { subject, single } \\
\text { dose }\end{array}$ & $\begin{array}{l}300 \mathrm{~mL} \text { of GR } \\
\text { infusion }\end{array}$ & nd & $\begin{array}{l}\text { Methylated ASP; methylated and } \\
\text { glucuronidated ASP }\end{array}$ & $\begin{array}{l}\text { Max. conc. } \\
\text { reached }<2 \mathrm{~h} \text { after } \\
\text { ingestion; } 0.74 \% \\
\text { excreted during } \\
0-24 \mathrm{~h}\end{array}$ & [72] \\
\hline Human & $\begin{array}{l}41 \mathrm{mg} / \text { subject, single } \\
\text { dose }\end{array}$ & $\begin{array}{l}500 \mathrm{~mL} \text { GR } \\
\text { "ready-to-drink" } \\
\text { beverage }\end{array}$ & nd & $\begin{array}{l}\text { Glucuronidated ASP (2); methylated } \\
\text { and glucuronidated ASP (3); methy- } \\
\text { lated and sulphated ASP; sulphated } \\
\text { ASP }\end{array}$ & $\begin{array}{l}\text { Most excreted } \\
<5 \mathrm{~h} \text { after inges- } \\
\text { tion; } 0.22 \% \\
\text { excreted during } \\
0-24 \mathrm{~h}\end{array}$ & [36] \\
\hline Human & $\begin{array}{l}3.6 \mathrm{mg} / \text { subject, } \\
\text { single dose }\end{array}$ & $\begin{array}{l}500 \mathrm{~mL} \text { fer- } \\
\text { mented rooibos } \\
\text { "ready-to-drink" } \\
\text { beverage }\end{array}$ & nd & $\begin{array}{l}\text { methylated and glucuronidated ASP } \\
\text { (3); methylated and sulphated ASP; } \\
\text { sulphated ASP }\end{array}$ & $\begin{array}{l}0.09 \% \text { excreted } \\
\text { during } 0-24 \mathrm{~h}\end{array}$ & [36] \\
\hline Human & $\begin{array}{l}287 \mathrm{mg} / \mathrm{subject} \text {, } \\
\text { single dose }\end{array}$ & GR beverage & ASP & $\begin{array}{l}\text { ASP; glucuronidated ASP; methylated } \\
\text { ASP; methylated and glucuronidated } \\
\text { ASP (3); methylated and sulphated } \\
\text { ASP; sulphated ASP; glucuronidated } \\
\text { ASP aglycone }\end{array}$ & $\begin{array}{l}0.2 \% \text { excreted } \\
\text { during } 0-24 \mathrm{~h}\end{array}$ & [33] \\
\hline
\end{tabular}

\section{Metabolic syndrome and glucose metabolism}

Disturbances in glucose metabolism remain central to the aetiology of metabolic syndrome. In both the fed and fasted state, glucose-induced insulin secretion is tightly controlled, and disturbances in insulin action cause an imbalance between glucose uptake and consumption [94]. In the liver, insulin action promotes lipogenesis and glycogen synthesis, while lipolysis and glycogenolysis are inhibited [94]. Peripheral glucose absorption and usage are stimulated by insulin in adipose and muscle tissue. Insulin resistance dysregulates these processes, resulting in increased blood glucose levels with associated lipid accumulation [95].

Insulin action is mediated through the phosphorylation of various signalling cascades, culminating in glucose uptake into the cell. Simply put, activation of PI3K/AKT by IRS- 1 phosphorylates GSK3- $\beta$ and initiates GLUT4 translocation from the cytosol to the cell membrane [96]. Both PI3K and AKT are crucial kinases that regulate GLUT4 translocation and have subsequently gathered significant interest as possible drug targets for treating the metabolic syndrome $[94,96]$. Conversely, in an obese or type 2 diabetic state, elevated DAG and ceramide levels can activate PKC, leading to a dysregulated IRS/PI3K/AKT cascade that suppresses GLUT4- mediated glucose uptake in muscle and adipose tissues, as is observed in AKT knockout mice [97].

Although the PI3K/AKT signalling pathway is essential in the regulation of insulin-stimulated glucose uptake, glucose can also be regulated by phosphorylated AMPK in an insulin-independent manner [92]. AMPK is a major energy sensor that plays a critical role in cellular homeostasis and has been widely studied as a possible target to improve insulin resistance [98]. Through its maintenance of energy consumption, AMPK has contributed significantly to the modulation of various cellular processes, including cell growth, autophagy, and glucose metabolism [98]. For the latter, it is postulated that upon activation, AMPK promotes GLUT4 translocation to the cell membrane, resulting in increased glucose uptake in skeletal muscle and adipose tissue $[99,100]$. Metformin, a biguanide class of oral antidiabetic, mediates its antidiabetic actions by indirectly activating AMPK [101]. However, contradicting evidence also shows that activation of AMPK in a diabetic heart can contribute to the inhibition of glucose utilisation, while abnormally enhancing fatty acid oxidation that can lead to accelerated myocardial apoptosis [102-104]. Thus, in addition to the modulation of PI3K/AKT signalling, optimal regulation of AMPK remains 
essential in promoting glucose uptake, reversing insulin resistance, and attenuating metabolic disease-associated complications such as oxidative stress and inflammation $[98,103]$.

\section{Metabolic syndrome and lipid metabolism}

Lipid metabolism can be defined as the synthesis or break down of fats for energy, a process that plays a major role in normal body function, as well as the aetiology of metabolic syndrome [105]. Fatty acids are major components of triglycerides and can either be absorbed through the ingestion of food or synthesised by adipocytes or hepatocytes from carbohydrate precursors such as acetyl-CoA [105]. This process begins in the intestine where triglycerides are degraded by pancreatic lipases and bile salts into FFAs, where they, together with cholesterol molecules, are packed into chylomicrons, which are transported within the lymphatic and circulatory system to be metabolised by cells or stored in the adipose tissue [106]. Although adipose tissue is the largest energy reserve in mammals, fats are also stored in muscle and liver tissues [106]. In muscle, fat stores are used as a substrate for fatty acid $\beta$-oxidation, whereas in the liver, fats are utilised in the synthesis of triacylglycerol for energy [106]. To obtain energy from adipocytes, fats are hydrolysed into FFAs and glycerol molecules in a process called lipolysis. These FFAs are further oxidised during mitochondrial fatty acid $\beta$-oxidation to produce acetyl-CoA, which is a major substrate required in the Krebs cycle for the production of energy in the form of ATP [105].

Fatty acid $\beta$-oxidation produces twice the amount of energy compared to carbohydrate or glucose metabolism and its dysregulation is implicated in the aetiology of the metabolic syndrome [107]. Altered $\beta$-oxidation in the muscle and liver is associated with diabesity (co-occurrence of type 2 diabetes and obesity) and an increased cardiovascular risk [108]. During the progression of obesity, increased lipogenesis and diminished $\beta$-oxidation account for augmented hepatic expression of lipogenic genes including SCD1, PPAR $y$, and SREBP1/2. In muscle, increased levels of long-chain FFA acyl-CoAs together with their lipid intermediate metabolites, DAG and ceramide, impede insulin action through activation of PKC [109]. Activation of PKC initiates an increased inflammatory response that augments muscle insulin resistance via activation of IRS (serine 307) (IRS $^{\text {Ser307}}$ ). As previously explained, this process attenuates peripheral glucose uptake and translocation of GLUT4. Nevertheless, enhanced oxidative stress appears to be one of the devastating factors associated with accelerated tissue injury as a result of impaired glucose and lipid metabolism.

\section{Metabolic syndrome and oxidative stress}

It is generally accepted that oxidative stress plays a major role in the development and exacerbation of the metabolic syndrome. The role of persistent exposure to high glucose (chronic hyperglycaemia), linked to the increased production of ROS within the disease state, is well established [110]. In diabetes, raised blood glucose levels induce various signalling pathways associated with the aggravation of oxidative stress. For example, activation of the sorbitol-aldose reductase pathway, a key process in the control of excess blood glucose, can cause a decrease in the reduced form of NADP, i.e., NADPH. It is well known that the NADPH cofactor plays a major role in the synthesis of GSH, an essential antioxidant that detoxifies intracellular ROS [111]. Moreover, intracellular reduction of NADPH and GSH may promote the production of nitric oxide as well as chain activation of other free radicals leading to accelerated oxidative damage [112].

Some of the well-known sources responsible for exacerbated generation of oxidative stress in many cell types include glucose autoxidation (normally identified with elevated glucose levels in a diabetic state), abnormally enhanced activity of NADPH and xanthine oxidases, and the overactivity of the mitochondrial electron transport chain [113-115]. Lipid peroxidation, which may arise as a result of oxidative degradation of lipids by increased free radical production, is a widely-reported phenomenon identified in obese individuals $[116,117]$. Avci et al. [117] recently showed that enhanced lipid peroxidation inversely correlates with GSH content in individuals with metabolic syndrome. This was supported by others demonstrating that systemic markers of lipid peroxidation such as oxidised LDL and TBARS are elevated in individuals with metabolic syndrome compared to control subjects $[118,119]$. Such findings have also been supported by data from animal models of metabolic syndrome with increased liver dysfunction, muscle insulin resistance, and subsequent cardiomyocyte remodelling and apoptosis $[83,84,88]$.

\section{Metabolic syndrome and inflammation}

Another devastating consequence interrelated with oxidative stress that normally arises due to prolonged exposure to elevated blood glucose (hyperglycaemia) and circulating lipids (hyperlipidaemia) is the activation of inflammation. Although an inflammatory response is necessary for debridement after injury, tenacious inflammation is thought to exacerbate cell damage under various disease conditions [85]. In an obese state, a proinflammatory response results in the infiltration of macrophages into peripheral tissues, including adipose tissue and the liver as well as skeletal and heart muscle $[120,121]$. In adipose tissue, the macrophage infiltration stems from excessive lipid overload of the various adipose tissue deposits, caused by adipocyte hypertrophy and hyperplasia, culminating in ischaemic tissue congestion and dysfunction [122]. In the liver, the nutrient overload causes nonalcoholic fatty liver disease [123]. Furthermore, increased lipid stores, particularly visceral adiposity, promote a low-grade systemic proinflammatory response, activating $\mathrm{M} 1$ macrophages (Th1 response) to secrete elevated levels of MCP1, IL-6, IL-1 $\beta$, TNF- $\alpha$, and leptin, while repressing adiponectin levels $[124,125]$. Adiponectin is an important adipokine that is secreted by adipocytes and is known to play a significant role in obesity-induced insulin resistance. Numerous animal studies have shown that increased adiponectin levels are inversely proportional to the concentration of ceramides, an important factor in the modulation of obesity-induced insulin resistance $[126,127]$. Additional evidence shows that adiponectin levels are negatively correlated with increased TNF- $\alpha$ levels $[121,124,126]$. Likewise, growing evidence suggests that decreased adiponectin levels with concomitant increased TNF- $\alpha$ levels not only perpetuate obesity-induced insulin resistance, but are key cytokines that aggravate the metabolic syndrome [127, 128]. Increased adiponectin levels are associated with diminished systemic inflammation and lipid accumulation, leading to reduced vascular dysfunction that is linked to the metabolic syndrome 
[129]. Indeed, reduced adiponectin levels negatively correlate with the degree of adiposity and inflammation as indicated by decreased IL- 6 and TNF- $\alpha$ production, both key mediators of diabesity-induced cardiac dysfunction $[130,131]$. Thus, understanding the process that regulates TNF- $\alpha$-induced inflammation and subsequent insulin resistance is key to unravelling possible drug targets for therapeutic intervention.

According to Kwon and Pessin [124], TNF- $\alpha$ can induce insulin resistance through two possible mechanisms, i.e., the initiation and propagation of lipolysis or by directly blunting insulin signalling. In the obese state, TNF- $\alpha$-induced lipolysis leads to an escalation in the availability of circulating FFAs, and this exacerbates insulin resistance and ectopic fat accumulation in organs such as the liver and muscle [132]. In the liver, this enhanced FFA delivery together with an increase in endoplasmic reticulum stress can lead to the activation of several kinases, including JNK and IKK/NF- $\kappa \mathrm{B}$, which further contribute to the impairment of insulin resistance through the phosphorylation of IRS ${ }^{\text {Ser307 }}[120,133]$. In addition, excessive de novo hepatic lipogenesis causes an increase in FFA flux, which inhibits $\beta$-oxidation through increased expression of long-chain acyl-CoA. This in turn augments the hepatic triglyceride pool, which is exacerbated through an alternative mechanism that implicates the upregulated expression of SREBP-1c [134, 135].

The escalation of lipid accumulation further triggers increased dyslipidaemia, in the form of VLDL and LDL concomitant to raised proinflammatory markers such as macrophages and leukocytes within the vascular wall $[124,136]$. This process, together with elevated TNF- $\alpha$ levels increase the expression of CAM, P-selectin, and E-selectin, to the vascular endothelium, resulting in an acute localised cellular inflammatory response that triggers plaque development and cardiovascular dysfunction [121,123,137]. Similarly, in skeletal muscle of obese insulin-resistant individuals, TNF- $\alpha$ enhances the expression of proinflammatory cytokines in response to increased lipid storage with a concomitant reduction of $\beta$-oxidation, leading to abnormally elevated ceramide levels that augment muscle insulin resistance through PKC activation [94].

\section{Protective Potential of Aspalathin against Metabolic Disease-Associated Complications}

\section{Effect of aspalathin on glucose and lipid metabolism}

A growing body of evidence demonstrates that dietary supplements such as polyphenols, displaying antioxidant and anti-inflammatory properties, can exert beneficial effects on essential signalling molecules involved in carbohydrate and lipid metabolism [138]. Rooibos and its phenolic constituents, including aspalathin, are progressively explored for their ameliorative effects on metabolic syndrome and associated complications, including obesity and diabetes mellitus ( $\bullet$ Table 6 ). For example, in type 2 diabetic $(d b / d b)$ mice and cultured pancreatic $\beta$-cells, aspalathin was shown to be effective at improving glucose tolerance and stimulating insulin secretion, respectively [139]. Consistent with these findings, Muller et al. [140] showed that an aspalathin-rich green rooibos extract and pure aspalathin are able to modulate glucose metabolism by inhibiting $\alpha$-glucosidase enzyme activity and promoting glucose uptake in pancreatic and skeletal muscle cells as well as improving glucose tolerance in streptozotocin-induced diabetic Wistar rats. Mikami et al. [141] demonstrated that green rooibos extract and aspalathin were effective at reducing blood glucose levels of nondiabetic mice following ingestion of glucose, sucrose, and starch solutions, while suppressing the activities of $\alpha$-glucosidase and $\alpha$-amylase, key enzymes involved in carbohydrate hydrolysis. Mazibuko et al. [92,142] further investigated the molecular mechanisms associated with the ameliorative effect of pure aspalathin and an aspalathin-rich green rooibos extract on palmitate-induced insulin resistance in $\mathrm{C} 2 \mathrm{C} 12$ myotubes and 3T3-L1 adipocytes. Both the extract and compound were able to reverse palmitate-induced insulin resistance by increasing levels of GLUT4 through the suppression of PKC and NF- $K B$, while activating AMPK. Son et al. [143] supported these findings showing that aspalathin treatment improved glucose tolerance in obese (ob/ob) mice, while similarly enhancing glucose uptake by promoting AMPK phosphorylation and GLUT4 translocation in L6 myotubes. Smit et al. [144] showed that aspalathin promotes insulin sensitivity in cardiomyocytes from young and aged rats, but not in high-caloric diet animals, through a PI3K-dependent mechanism. Aspalathin can protect cardiomyocytes from doxorubicin-induced cardiotoxicity by increasing autophagy, while simultaneously decreasing apoptosis [102, 145].

Furthermore, both in vitro and in vivo studies have indicated that aspalathin can reduce hyperlipidaemia [91, 146]. The effect of aspalathin to diminish cholesterol, triglycerides, and VLDL and LDL cholesterol levels, while increasing high-density lipoprotein cholesterol levels, has been investigated in a few studies. Najafian et al. [146] showed that streptozotocin-induced diabetic male Wistar rats receiving 5,10 , and $40 \mathrm{mg} / \mathrm{kg}$ of aspalathin for 21 days displayed a dose-dependent decrease in lipid levels in conjunction with reduced blood glucose concentrations. Similarly, in a study by Johnson et al. [91], a 6-week treatment with aspalathin modulated lipoprotein clearance in a dose-dependent manner in $d b / d b$ mice, with a higher dose $(130 \mathrm{mg} / \mathrm{kg})$ of the compound being more effective than a lower dose $(13 \mathrm{mg} / \mathrm{kg})$. Additional evidence by Van der Merwe et al. [147] demonstrated that an aspalathinrich green rooibos extract significantly reduced serum total cholesterol of male Fischer rats after 90 days of treatment. Collectively, these results indicate that aspalathin may beneficially modulate glucose and lipid metabolism, thereby ameliorating the complications associated with metabolic syndrome.

\section{The proposed cellular mechanisms by which aspalathin improves glucose and lipid metabolism}

The cellular mechanism by which aspalathin targets metabolic syndrome and improves glucose and lipid clearance remains to be fully elucidated. However, it has been proposed that by supressing fatty acid synthesis, aspalathin enhances CPT1 expression and subsequently increases $\beta$-oxidation in muscle tissue [92]. The latter process is under the control of essential lipid metabolism genes, including ACC, FAS, and SCD1, that play an integral role in the development of insulin resistance in fat, liver, muscle, and heart tissue. Furthermore, PPAR $y$, SREBP-1/2, and 
Table 6 Summary of studies related to the antioxidant, antidyslipidaemic, antidiabetic, and anti-inflammatory activities of aspalathin (ASP) and aspalathin-rich green rooibos extracts.

\begin{tabular}{|c|c|c|c|}
\hline Experimental model & Treatment and dose & Experimental outcome & Reference \\
\hline $\begin{array}{l}\text { L6 Myoblasts, RIN-5F cells } \\
\text { and type } 2 \text { diabetic }(d b / d b) \\
\text { mice }\end{array}$ & $\begin{array}{l}\text { ASP: Cell culture dose }(1-100 \mu \mathrm{M}) \\
\text { ASP: Dietary dose in mice }(0.1-0.2 \%)\end{array}$ & $\begin{array}{l}\text { Improved glucose uptake, insulin secretion, and } \\
\text { glucose tolerance. }\end{array}$ & [139] \\
\hline $\begin{array}{l}\text { Online HPLC-biochemical } \\
\text { assay for } \alpha \text {-glucosidase in- } \\
\text { hibitory activity, C2C12 } \\
\text { myotubules, Chang (CCL- } \\
\text { 13) cells, and streptozoto- } \\
\text { cin-induced diabetic rats }\end{array}$ & $\begin{array}{l}\text { ASP: Cell culture dose }(1,10 \text {, and } 100 \mu \mathrm{M}) \\
\text { Extract: Cell culture dose }\left(5 \times 10^{-5}-5 \mu \mathrm{g} / \mathrm{mL}\right) \\
\text { Extract: In vivo dose }(3,25,30 \text {, or } 300 \mathrm{mg} / \mathrm{kg} \mathrm{BW})\end{array}$ & $\begin{array}{l}\text { Displayed } \alpha \text {-glucosidase inhibitory activity, im- } \\
\text { proved glucose tolerance, and dyslipidaemia. }\end{array}$ & {$[140,146]$} \\
\hline $\begin{array}{l}\text { Nondiabetic ddY mice; in } \\
\text { vitro } \alpha \text {-glucosidase and } \\
\alpha \text {-amylase inhibitory assays }\end{array}$ & $\begin{array}{l}\text { ASP: In vitro dose }(0,0.5,1,2,4,8 \mathrm{mg} / \mathrm{mL}) \\
\text { ASP: In vivo dose }(20 \mathrm{mg} / \mathrm{mL} / 100 \mathrm{~g} \mathrm{BW}) \\
\text { Extract: In vitro dose }(0,2.5,5,10,20,40 \mathrm{mg} / \mathrm{mL}) \\
\text { Extract: In vivo dose }(80 \mathrm{mg} / \mathrm{mL} / 100 \mathrm{~g} \mathrm{BW})\end{array}$ & $\begin{array}{l}\text { Reduced blood glucose levels following ingestion of } \\
\text { glucose, sucrose, and starch solutions. Also inhibited } \\
\text { the activities of } \alpha \text {-glucosidase and } \alpha \text {-amylase. }\end{array}$ & {$[141]$} \\
\hline $\begin{array}{l}\text { L6 Myotubes, RIN-5F cells } \\
\text { and obese }(o b / o b) \text { mice }\end{array}$ & $\begin{array}{l}\text { ASP: Cell culture dose }(0-100 \mu \mathrm{M}) \\
\text { ASP: Dose in mice }(100 \mathrm{mg} / \mathrm{kg} / \text { day } / \text { mouse })\end{array}$ & $\begin{array}{l}\text { Dose-dependently increased glucose uptake, en- } \\
\text { hanced GLUT4 translocation to plasma membrane, } \\
\text { and promoted AMPK phosphorylation in L6 myo- } \\
\text { tubes. Reduced oxidative stress in RIN-5F cells and } \\
\text { improved fasting plasma glucose levels in mice. }\end{array}$ & {$[143]$} \\
\hline Caenorhabditis elegans & ASP: In vitro dose $(0,10,20,50 \mu \mathrm{M})$ & $\begin{array}{l}\text { Promoted longevity by targeting stress and ageing- } \\
\text { related genes, reducing the endogenous intracellu- } \\
\text { lar level of reactive oxygen species. }\end{array}$ & {$[152]$} \\
\hline $\begin{array}{l}\text { HUVECs, human blood } \\
\text { samples, and } \mathrm{C} 57 \mathrm{BL} / 6 \text { mice } \\
\text { (ex vivo model) }\end{array}$ & $\begin{array}{l}\text { ASP: Cell culture dose }(1-50 \mu \mathrm{M}) \\
\text { ASP: Ex vivo dose }(4.5,9.1,18.1,27.1 \text {, } \\
\text { and } 45.2 \mu \mathrm{g} / \text { mouse })\end{array}$ & $\begin{array}{l}\text { Demonstrated antithrombotic activities by prolong- } \\
\text { ing activated partial thromboplastin time and block- } \\
\text { ing platelet aggregation and activities of thrombin } \\
\text { and activated factor } X \text {. }\end{array}$ & {$[156]$} \\
\hline HUVECs and mice & $\begin{array}{l}\text { ASP: Cell culture dose }(1-50 \mu \mathrm{M}) \\
\text { ASP: In vivo dose }(4.5,9.1,27.1 \text {, or } 45.2 \mu \mathrm{g} / \text { mouse })\end{array}$ & $\begin{array}{l}\text { Prevented high-glucose-mediated vascular hyper- } \\
\text { permeability, adhesion of monocytes, and expres- } \\
\text { sion of cell adhesion molecules. Inhibited generation } \\
\text { of ROS and activation of NF-KB or ERKs. }\end{array}$ & $\begin{array}{l}{[157,162,} \\
163]\end{array}$ \\
\hline HUVECS & ASP: Cell culture dose $(1-50 \mu \mathrm{M})$ & Ameliorated HMGB1-induced septic responses. & [159] \\
\hline 3T3-L1 Adipocytes & $\begin{array}{l}\text { ASP: Cell culture dose }(10 \mu \mathrm{M}) \\
\text { Extract: Cell culture dose }(10 \mu \mathrm{g} / \mathrm{mL})\end{array}$ & $\begin{array}{l}\text { Reversed palmitate-induced insulin resistance by } \\
\text { repressing NF- } к B \text {, IRS1 and AMPK phosphorylation, } \\
\text { and increased AKT activation; only the extract up- } \\
\text { regulated GLUT4 protein expression. }\end{array}$ & [92] \\
\hline $\begin{array}{l}\text { In vitro xanthine oxidase } \\
\text { inhibitory activity assay and } \\
\text { mice }\end{array}$ & ASP and extract: Effective dose used $(4.5 \mu \mathrm{g} / \mathrm{mL})$ & $\begin{array}{l}\text { Competitively inhibited xanthine oxidase. In hyper- } \\
\text { uricaemic mice, markedly suppressed increased } \\
\text { plasma uric acid levels in a dose-dependent manner. }\end{array}$ & {$[153]$} \\
\hline $\begin{array}{l}\text { H9c2 cells, } d b / d b \text { mice and } \\
\text { cardiomyocytes from rats }\end{array}$ & $\begin{array}{l}\text { ASP: Cell culture dose ( } 1 \text { and } 1000 \mu \mathrm{M}) \\
\text { ASP: In vivo dose ( } 13 \text { and } 130 \mathrm{mg} / \mathrm{kg} \mathrm{BW} / \text { day) }\end{array}$ & $\begin{array}{l}\text { Improved diabetes associated cardiac deregulations, } \\
\text { including enhanced glucose uptake, reversed im- } \\
\text { paired myocardial substrate metabolism, inhibited } \\
\text { inflammation, lipid storage, oxidative stress, and } \\
\text { cardiac remodelling. Reversed doxorubicin-induced } \\
\text { cardiotoxicity by activating AMPK and reducing tu- } \\
\text { mour protein p53 expression. }\end{array}$ & $\begin{array}{l}{[88,91} \\
102,144 \\
145]\end{array}$ \\
\hline Rats & Extract: In vivo dose of 29.5 mg/kg BW/day & $\begin{array}{l}\text { Lowered serum total cholesterol and iron levels, } \\
\text { whilst increasing alkaline phosphatase enzyme } \\
\text { activity and liver GSH levels. }\end{array}$ & {$[147,151]$} \\
\hline $\begin{array}{l}\text { Diabetic nonhuman } \\
\text { primates }\end{array}$ & Extract: In vivo dose (90 mg/kg BW) & $\begin{array}{l}\text { Improved glucose tolerance, reduced total choles- } \\
\text { terol, and LDL levels. Increased plasma coenzyme } \\
\text { Q10 and decreased oxidative status. }\end{array}$ & {$[154]$} \\
\hline
\end{tabular}

ChREBP are transcriptional factors that regulate and control the expression of these enzymes involved in the lipogenic process [148]. However, this process can be repressed through AMPK phosphorylation [149]. Aspalathin activates AMPK and reduces the expression of hepatic enzymes and transcriptional regulators that are associated with either gluconeogenesis and/or lipogenesis $[91,92,102,139,143,144,150]$. These studies proved that aspalathin controlled the balance between anabolism and catabo- 
lism through increased AMPK expression, while decreasing the expression of ACC, FAS, SCD1 and SREBP1 [91, 92, 143]. For example, Johnson et al. [91] showed that aspalathin protected vulnerable cardiomyocytes from diabetes-induced lipotoxicity by modulating adiponectin, ApoB, CD36, CPT1, PPARy, SREBP1/2, and SCD1, key regulators of lipid metabolism. Collectively, these results suggest that aspalathin acts on multiple targets associated with fatty acid synthesis and fatty acid oxidation, resulting in improved glucose and lipid metabolism.

\section{Effect of aspalathin on oxidative stress and inflammatory markers}

In addition to the strong antioxidant properties demonstrated by aspalathin in non-cell-based assays ( $\bullet$ Table 3 ), its capacity to enhance endogenous antioxidants and prevent oxidative stress was also shown in various experimental models ( $>$ Table 6). Administration of an aspalathin-enriched green rooibos extract to nondiabetic Fischer rats for 28 days increased GSH reductase activity (an important enzyme in the maintenance of the reduced form of GSH), however, a longer treatment period (90 days) reduced the GSH content in the liver, suggesting an altered GSH redox cycle $[147,151]$. Alternatively, Chen et al. [152] showed that a green rooibos extract improved the survival rate of Caenorhabditis elegans by reducing acute oxidative damage caused by the superoxide anion radical generator juglone. In RIN-5F pancreatic $\beta$-cells [143], aspalathin displayed an increased potential to prevent oxidative damage by suppressing ROS induced by advanced glycation end products. The robust antioxidant properties of aspalathin to reduce oxidative stress could be attributed to its inhibitory effect on xanthine oxidase, a known superoxide radical-producing enzyme [153]. Recently, Orlando et al. [154] showed that an aspalathin-rich green rooibos extract (12.8\% aspalathin content) administered at $90 \mathrm{mg} / \mathrm{kg}$ three times daily with meals to high-fat fed diabetic vervet monkeys protected against LDL oxidation and preserved endogenous coenzyme Q10 levels. This supports outcomes of the study by Marnewick et al. [155], showing that the consumption of six cups of rooibos tea improved plasma lipid and oxidative stress levels in adults at risk for developing cardiovascular disease.

Recent studies from our laboratory have also reported on the potential of aspalathin to protect cardiac cells against oxidative stress-associated damage ( $\vee$ Table 6 ). In cardiomyocytes isolated from diabetic rats, a fermented rooibos extract ( $0.36 \%$ aspalathin) prevented ROS-induced apoptosis by increasing intracellular GSH levels [161]. Furthermore, in cardiomyocytes exposed to a high glucose concentration, the capacity of aspalathin to prevent oxidative damage was associated with its modulatory effect on glucose and lipid metabolism, specifically by reducing abnormally increased FFA uptake and oxidation through the reduced phosphorylation of AMPK [102]. AMPK is a major energy regulator that plays a role in the reversal of peripheral insulin resistance through the modulation of $\beta$-oxidation $[92,142,143]$. This kinase increases $\beta$-oxidation and improves peripheral insulin sensitivity through phosphorylation and inactivation of ACC, a rate-limiting enzyme in fatty acid synthesis and subsequent $\beta$-oxidation. However, in the diabetic heart, an abnormal increase in fatty acid oxidation, as opposed to glucose oxidation, has been linked to reduced car- diac efficiency. In a recent study [102], we showed that in the diabetic heart, aspalathin modulates AMPK hyperactivation and improves glucose oxidation. This favourable shift in cardiac energy substrate, in favour of glucose oxidation, is believed to be important to protect a diabetic heart at risk of developing heart failure. The ameliorative effects of aspalathin were confirmed in the hearts of $d b / d b$ mice and cardiomyocytes exposed to high glucose concentrations [88], showing that an increased expression of $\mathrm{Nrf2}$, an essential transcriptional factor that is upregulated in response to oxidative stress and other stresses associated with the metabolic syndrome [89], plays a partial role in the protective effect of aspalathin. This study further showed that the upregulated expression of Nrf2 enhanced the endogenous antioxidant systems such as GSH and superoxide dismutase, as well as UCP2, resulting in improved cardiac ultrastructure. Although these findings need to be confirmed in other models, the results infer that aspalathin might be a useful therapeutic against endogenous oxidative stress and protect cardiovascular cells from diabetes-associated complications.

In addition to the ability of aspalathin to reduce oxidative stress, anti-inflammatory properties have also been demonstrated for this dihydrochalcone. Lipopolysaccharide is a known means of inducing vascular inflammation, both in in vitro and in vivo models. Aspalathin treatment suppressed lipopolysaccharide-induced membrane permeability and CAM in both human endothelial cells and in mice [162]. Furthermore, aspalathin ablated this effect by downregulating the expression of TNF- $\alpha$, IL-6, and NF- $\kappa$ B. In a follow-up study, the authors demonstrated that $10-30 \mu \mathrm{M}$ of aspalathin averted HMGB1-mediated vascular inflammation and hyperpermeability by inhibiting the expression of CAM in both an in vitro (HUVECs) and in vivo (C57BL/6 mouse) model [158]. Although additional evidence is required to confirm these findings, a study by Ku et al. [157] showed aspalathin suppressed ROS as well as activated NF- $K \mathrm{~B}$ and monocyte adhesion in both an in vitro cell and in vivo mouse model. Elevated plasma levels of sEPCR have been found to increase vascular inflammation and subsequent thrombotic risk [159]. Kwak et al. [163] showed that aspalathin treatment inhibited phorbol 12-myristate 13-acetate-induced TNF- $\alpha$, IL-1 $\beta$, and CLP-induced EPCR shedding by inhibiting the phosphorylation of several kinases known to increase thrombin generation. These results present strong evidence in support of aspalathin as a nutraceutical to protect against metabolic syndrome and associated complications such as glucose and lipid intolerance, as well as oxidative stress and inflammation that may result in accelerated cell injury. The ameliorative properties of aspalathin against glucose and lipid metabolic perturbations in various tissue targets are summarised in $>$ Fig. 7 .

\section{Herb-drug interactions}

The increasing custom of the health conscious public to supplement their diets with natural products to enhance health and well-being is of concern due to possible herb-drug interactions in the growing population of patients on chronic medications [164]. Natural products are generally considered to be safe with little regard for potential adverse effects. Patients are drawn to using these products as adjunctive supplements to enhance the therapeutic efficacy of their medication, mostly without informing 


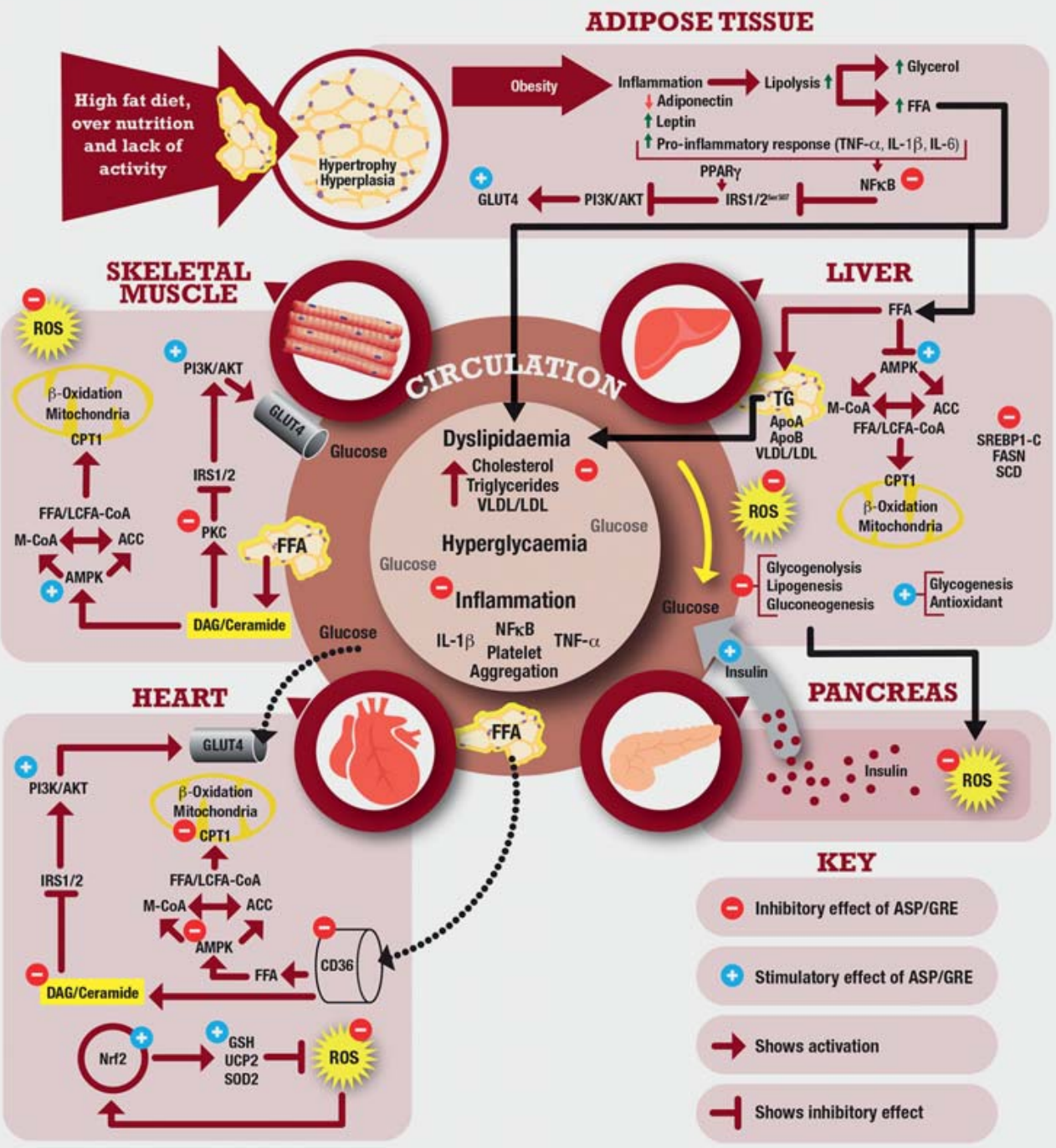

- Fig. 7 Summary of the ameliorative properties of aspalathin (ASP) and/or aspalathin-enriched green rooibos extract (GRE) against glucose and lipid metabolic perturbations as observed in in vitro and in vivo models. An obesogenic environment, characterised by over-nutrition and lack of physical activity, promotes excess lipid accumulation, development of insulin resistance, and metabolic syndrome. In adipose tissue, increased hypertrophy and hyperplasia of adipocytes result in the activation of $\mathrm{NF}-\mathrm{kB}$, an inflammatory kinase known to suppress insulin signalling and exacerbate inflammation. Aspalathin effectively ameliorated these metabolic complications by improving insulin response, the result of enhanced GLUT4 expression, and inhibition of NF-KB-induced inflammation. In the liver, aspalathin suppressed cholesterol synthesis by decreasing SREBP1-C, a transcriptional factor involved in fat synthesis, and by decreasing glucose release from the liver, facilitated by gluconeogenesis and glycogenolytic enzymes. In the pancreas, aspalathin exerted its effects by suppressing ROS induced by advanced glycation end products, and by stimulating insulin secretion. In the heart, aspalathin suppressed abnormally increased FFA oxidation resulting in improved cardiac energy metabolism, and prevented oxidative damage by upregulating Nrf2. In the skeletal muscle, aspalathin improved insulin signalling by reversing the inhibitory effect of PKC on IRS1/2, thereby increasing glucose uptake and $\beta$-oxidation and reducing ROS.

their health practitioner. In most countries, natural products are sold over-the-counter or are freely available in supermarkets with sparse information about their health risk benefits, either as a monotherapy or in combination with other chronic medications. It is reasonable to assume that the concurrent use of aspalathinbased nutraceuticals with chronic blood glucose-lowering medication by type 2 diabetic patients will escalate. Although anecdotal evidence suggests that consumption of rooibos is generally regarded as safe, recently, two case studies have suggested the po- tential for herb-drug hepatotoxicity. In the first case [165], a 42year-old woman treated for a low-grade B-cell malignancy with rituximab and maintained on prednisolone and co-trimoxazole daily, presented with elevated liver enzymes. She was advised to stop drinking rooibos flavoured with small amounts of strawberry, chamomile, and petals of daisy and discontinue her prophylactic antibiotic (co-trimoxazole). One week later, her liver enzymes returned to normal and she resumed her prophylactic co-trimoxazole treatment without further adverse effects. A second case 
study $[166,167]$ involved a 52-year-old hyperlipidaemic patient on atorvastatin who developed clinical symptoms of hepatotoxicity following increased consumption of a rooibos-buchu herbal tea. In the latter case, the presence of buchu, an indigenous South African medicinal plant shown to inhibit CYP3A4 [160], a major phase I metabolising enzyme of atorvastatin, confounded results. Although these two case studies do not conclusively infer causality, the sparsity of information relating to the potential of rooibosand aspalathin-drug interactions prompted us to investigate their potential interaction with chronic medications such as statins or oral hypoglycaemic drugs. Using an in vitro recombinant CYP450 enzyme assay, both an aspalathin-rich green rooibos extract and aspalathin dose- and time-dependently inhibited CYP3A4, cautioning against the potential of a herb-drug interaction with hypoglycaemic drugs such as sulfonylureas and statins, including atorvastatin [168]. However, these findings still need to be confirmed by in vivo pharmacokinetic and pharmacodynamic studies.

\section{Conclusions}

The increase in metabolic syndrome, partially due to a sedentary lifestyle and poor diet, and consumers looking for "quick fix answers" create increasing opportunities for the development of natural products to manage clinical risks such as increased blood sugar and cholesterol. Such products need scientific scrutiny to understand the mechanisms of action and ensure safety with minimum adverse reactions. Research to date on aspalathin and aspalathin-rich green rooibos extracts has laid the foundation for their use as adjunctive therapeutics. Issues that need to be addressed are effective dose, safety, potential herb-drug interactions, and improved bioavailability of aspalathin.

\section{Conflict of Interest}

The authors declare no conflict of interest.

\section{References}

[1] McKee F, Hawkins B. Phlorhizin glucosuria. Physiol Rev 1945; 25: 255280

[2] Swain T. Economic Importance of flavonoid Compounds: Foodstuffs. In: Geissman T, ed. The Chemistry of flavonoid Compounds. London, UK: Pergamon Press; 1962: 513-552

[3] Idris I, Donnelly R. Sodium-glucose co-transporter-2 inhibitors: an emerging new class of oral antidiabetic drug. Diabetes Obes Metab 2009; 11: 79-88

[4] Jesus AR, Vila-Viçosa D, Machuqueiro M, Marques AP, Dore TM, Rauter AP. Targeting type 2 diabetes with C-glucosyl dihydrochalcones as selective sodium glucose co-transporter 2 (SGLT2) inhibitors: synthesis and biological evaluation. J Med Chem 2017; 60: 568-579

[5] Blaschek W. Natural products as lead compounds for sodium glucose cotransporter (SGLT) inhibitors. Planta Med 2017; 83: 985-993

[6] Liu W, Wang H, Meng F. In silico modeling of aspalathin and nothofagin against SGLT2. J Theor Comput Chem 2015; 14: 1550056

[7] PubChem Compound Database CID: 11282394. National Center for Biotechnology Information. Available at https://pubchem.ncbi.nlm.nih. gov/compound/11282394. Accessed September 13, 2017
[8] Chemspider CSID: 9457391. Available at http://www.chemspider.com/ Chemical-Structure9457391.html. Accessed September 13, 2017

[9] Koeppen BH, Roux DG. Aspalathin: a novel C-glycosylflavonoid from Aspalathus linearis. Tetrahedron Lett 1965; 39: 3497-3503

[10] Bowles S, Joubert E, De Beer D, Louw J, Brunschwig C, Njoroge M, Lawrence N, Wiesner L, Chibale K, Muller C. Intestinal transport characteristics and metabolism of C-glucosyl dihydrochalcone, aspalathin. Molecules 2017; 22: E554

[11] Huang M, Du Plessis J, Du Preez J, Hamman J, Viljoen A. Transport of aspalathin, a rooibos tea flavonoid, across the skin and intestinal epithelium. Phyther Res 2008; 22: 699-704

[12] Behzad S, Sureda A, Barreca D, Nabavi SF, Rastrelli L, Nabavi SM. Health effects of phloretin: from chemistry to medicine. Phytochem Rev 2017; 16: 527-533

[13] Dahlgren R. Revision of the genus Aspalathus. II. The species with ericoid and pinoid leaflets. 7. Subgenus Nortieria. With remarks on rooibos tea cultivation. Bot Not 1968; 121: 165-208

[14] Dahlgren R. Crotalarieae (Aspalathus). Flora South Africa 1988; 16: 8490

[15] Stander M, Van Wyk B, Taylor MJC, Long HS. Analysis of phenolic compounds in rooibos tea (Aspalathus linearis) with a comparison of flavonoid-based compounds in natural populations of plants from different regions. J Agric Food Chem 2017; 65: 10270-10281

[16] Van Wyk BE, Gorelik B. The history and ethnobotany of Cape herbal teas. South African J Bot 2017; 110: 18-38

[17] Malgas RR, Potts AJ, Oettlé NM, Koelle B, Todd SW, Verboom GA, Hoffman MT. Distribution, quantitative morphological variation and preliminary molecular analysis of different growth forms of wild rooibos (Aspalathus linearis) in the northern Cederberg and on the Bokkeveld Plateau. South African J Bot 2010; 76: 72-81

[18] Hawkins H], Malgas R, Biénabe E. Ecotypes of wild rooibos (Aspalathus linearis (Burm. F) Dahlg., Fabaceae) are ecologically distinct. South African | Bot 2011; 77: 360-370

[19] Van Heerden FR, Van Wyk BE, Viljoen AM, Steenkamp PA. Phenolic variation in wild populations of Aspalathus linearis (rooibos tea). Biochem Syst Ecol 2003; 31: 885-895

[20] Joubert E, Schulz H. Production and quality aspects of rooibos tea and related products. A review. J Appl Bot Food Qual 2006; 80: 138-144

[21] Joubert E, De Beer D, Malherbe C], Muller N, Bonnet SL, Van der Westhuizen JH, Ferreira D. Occurrence and sensory perception of Z-2-( $\beta$-Dglucopyranosyloxy)-3-phenylpropenoic acid in rooibos (Aspalathus linearis). Food Chem 2013; 136: 1078-1085

[22] Joubert E, De Beer D. Rooibos (Aspalathus linearis) beyond the farm gate: From herbal tea to potential phytopharmaceutical. South African J Bot 2011; 77: 869-886

[23] Koch IS, Muller M, Joubert E, Van der Rijst M, Næs T. Sensory characterization of rooibos tea and the development of a rooibos sensory wheel and lexicon. Food Res Int 2012; 46: 217-228

[24] Jolley B, Van der Rijst M, Joubert E, Muller M. Sensory profile of rooibos originating from the Western and Northern Cape governed by production year and development of rooibos aroma wheel. South African J Bot 2017; 110: 161-166

[25] De Beer D, Miller N, Joubert E. Production of dihydrochalcone-rich green rooibos (Aspalathus linearis) extract taking into account seasonal and batch-to-batch variation in phenolic composition of plant material. South African J Bot 2017; 110: 138-143

[26] Joubert E, De Beer D. Phenolic content and antioxidant activity of rooibos food ingredient extracts. J Food Compos Anal 2012; 27: 45-51

[27] Viljoen M, Muller M, De Beer D, Joubert E. Identification of broad-based sensory attributes driving consumer preference of ready-to-drink rooibos iced tea with increased aspalathin content. South African J Bot 2017; 110: 177-183 
[28] Muller CJF, Malherbe C], Chellan N, Yagasaki K, Miura Y, Joubert E. Potential of rooibos, its major $C$-glucosyl flavonoids and $Z$-2- $(\beta$-D-glucopyranosyloxy)-3-phenylpropenoic acid in prevention of metabolic syndrome. Crit Rev Food Sci Nutr 2018; 58: 227-246

[29] Joubert E, Beelders T, De Beer D, Malherbe C], De Villiers A, Sigge GO. Variation in phenolic content and antioxidant activity of fermented rooibos herbal tea infusions: role of production season and quality grade. J Agric Food Chem 2012; 60: 9171-9179

[30] De Beer D, Malherbe C], Beelders T, Willenburg EL, Brand DJ, Joubert E. Isolation of aspalathin and nothofagin from rooibos (Aspalathus linearis) using high-performance countercurrent chromatography: sample loading and compound stability considerations. J Chromatogr A 2015; 1381: 29-36

[31] Joubert E. HPLC quantification of the dihydrochalcones, aspalathin and nothofagin in rooibos tea (Aspalathus linearis) as affected by processing. Food Chem 1996; 55: 403-411

[32] Bramati L, Minoggio M, Gardana C, Simonetti P, Mauri P, Pietta P. Quantitative characterization of flavonoid compounds in rooibos tea (Aspalathus linearis) by LC-UV/DAD. J Agric Food Chem 2002; 50: 5513-5519

[33] Breiter T, Laue C, Kressel G, Gröll S, Engelhardt UH, Hahn A. Bioavailability and antioxidant potential of rooibos flavonoids in humans following the consumption of different rooibos formulations. Food Chem 2011; 128: $338-347$

[34] Beelders T, Sigge GO, Joubert E, De Beer D, De Villiers A. Kinetic optimisation of the reversed phase liquid chromatographic separation of rooibos tea (Aspalathus linearis) phenolics on conventional high performance liquid chromatographic instrumentation. J Chromatogr A 2012; 1219: 128-139

[35] Schulz H, Joubert E, Schütze W. Quantification of quality parameters for reliable evaluation of green rooibos (Aspalathus linearis). Eur Food Res Technol 2003; 216: 539-543

[36] Stalmach A, Mullen W, Pecorari M, Serafini M, Crozier A. Bioavailability of C-linked dihydrochalcone and flavanone glucosides in humans following ingestion of unfermented and fermented rooibos teas. J Agric Food Chem 2009; 57: 7104-7111

[37] Walters NA, De Villiers A, Joubert E, De Beer D. Improved HPLC method for rooibos phenolics targeting changes due to fermentation. J Food Compos Anal 2017; 55: 20-29

[38] Kazuno S, Yanagida M, Shindo N, Murayama K. Mass spectrometric identification and quantification of glycosyl flavonoids, including dihydrochalcones with neutral loss scan mode. Anal Biochem 2005; 347: 182192

[39] Arries W], Tredoux AG, De Beer D, Joubert E, De Villiers A. Evaluation of capillary electrophoresis for the analysis of rooibos and honeybush tea phenolics. Electrophoresis 2017; 38: 897-905

[40] Koeppen B. The Ethyl Acetate soluble Polyphenols of Rooibos Tea. [MSc in Food Technology thesis]. Stellenbosch, South Africa: Stellenbosch University; 1959

[41] Koeppen B. The flavonoid Constituents of Aspalathus acuminatus. [PhD in Food Technology thesis]. Stellenbosch, South Africa: Stellenbosch University; 1961

[42] Koeppen BH, Roux DG. C-glycosylflavonoids. The chemistry of aspalathin. Biochem J 1966; 99: 604-609

[43] Rabe C, Steenkamp JA, Joubert E, Burger JFW, Ferreira D. Phenolic metabolites from rooibos tea (Aspalathus linearis). Phytochemistry 1994; 35: 1559-1565

[44] Marais C, Van Rensburg WJ, Ferreira D, Steenkamp JA. (S)- and (R)-eriodictyol-6-C- $\beta$-D-glucopyranoside, novel keys to the fermentation of rooibos (Aspalathus linearis). Phytochemistry 2000; 55: 43-49

[45] Krafczyk N, Glomb MA. Characterization of phenolic compounds in rooibos tea. J Agric Food Chem 2008; 56: 3368-3376
[46] Krafczyk N, Heinrich T, Porzel A, Glomb MA. Oxidation of the dihydrochalcone aspalathin leads to dimerization. J Agric Food Chem 2009; 57: 6838-6843

[47] Heinrich T, Willenberg I, Glomb MA. Chemistry of color formation during rooibos fermentation. J Agric Food Chem 2012; 60: 5221-5228

[48] Joubert E, Viljoen M, De Beer D, Manley M. Effect of heat on aspalathin, iso-orientin, and orientin contents and color of fermented rooibos (Aspalathus linearis) iced tea. J Agric Food Chem 2009; 57: 4204-4211

[49] Scalbert A, Johnson IT, Saltmarsh M. Polyphenols: antioxidants and beyond. Am J Clin Nutr 2005; 81: 215-217

[50] Joubert E, Gelderblom WCA, Louw A, De Beer D. South African herbal teas: Aspalathus linearis, Cyclopia spp. and Athrixia phylicoides - a review. J Ethnopharmacol 2008; 119: 376-412

[51] Fraga CG, Galleano M, Verstraeten SV, Oteiza PI. Basic biochemical mechanisms behind the health benefits of polyphenols. Mol Aspects Med 2010; 31: 435-445

[52] Joubert E, Winterton P, Britz T], Ferreira D. Superoxide anion and $\alpha, \alpha$-diphenyl- $\beta$-picrylhydrazyl radical scavenging capacity of rooibos (Aspalathus linearis) aqueous extracts, crude phenolic fractions, tannin and flavonoids. Food Res Int 2004; 37: 133-138

[53] Joubert E, Winterton P, Britz T], Gelderblom WCA. Antioxidant and prooxidant activities of aqueous extracts and crude polyphenolic fractions of rooibos (Aspalathus linearis). J Agric Food Chem 2005; 53: 1026010267

[54] Snijman PW, Joubert E, Ferreira D, Li XC, Ding Y, Green IR, Gelderblom WCA. Antioxidant activity of the dihydrochalcones aspalathin and nothofagin and their corresponding flavones in relation to other rooibos (Aspalathus linearis) flavonoids, epigallocatechin gallate, and Trolox. J Agric Food Chem 2009; 57: 6678-6684

[55] Von Gadow A, Joubert E, Hansmann CF. Comparison of the antioxidant activity of aspalathin with that of other plant phenols of rooibos tea (Aspalathus linearis), $\alpha$-tocopherol, BHT, and BHA. J Agric Food Chem 1997; 45: 632-638

[56] Krafczyk N, Woyand F, Glomb MA. Structure-antioxidant relationship of flavonoids from fermented rooibos. Mol Nutr Food Res 2009; 53: 635642

[57] Simpson M], Hjelmqvist D, López-Alarcón C, Karamehmedovic N, Minehan TG, Yepremyan A, Salehani B, Lissi E, Joubert E, Udekwu KI, Alarcon El. Anti-peroxyl radical quality and antibacterial properties of rooibos infusions and their pure glycosylated polyphenolic constituents. Molecules 2013; 18: 11264-11280

[58] Magcwebeba T, Swart P, Swanevelder S, Joubert E, Gelderblom W. Antiinflammatory effects of Aspalathus linearis and Cyclopia spp. extracts in a UVB/keratinocyte ( $\mathrm{HaCaT}$ ) model utilising interleukin-1 $\alpha$ accumulation as biomarker. Molecules 2016; 21: E1323

[59] Rezk BM, Van der Vijgh WJF, Bast A. The antioxidant activity of phloretin: the disclosure of a new antioxidant pharmacophore in flavonoids. Biochem Biophys Res Commun 2002; 295: 9-13

[60] Yepremyan A, Salehani B, Minehan TG. Concise total syntheses of aspalathin and nothofagin. Org Lett 2010; 12: 1580-1583

[61] Han Z, Achilonu MC, Kendrekar PS, Joubert E, Ferreira D, Bonnet SL, Van der Westhuizen $\mathrm{JH}$. Concise and scalable synthesis of aspalathin, a powerful plasma sugar-lowering natural product. J Nat Prod 2014; 77: 583-588

[62] Van der Westhuizen JH, Ferreira D, Joubert E, Bonnet SL. B2 Method for the synthesis of aspalathin and analogues thereof. US Patent US 9181293; 2015

[63] Zhang T, Fang Z. The concise synthesis and biological evaluation of $C$ glycosyl chalcone analogues inspired by the natural product aspalathin. RSC Adv 2017; 7: 3021-3024

[64] Bungaruang L, Gutmann A, Nidetzky B. Leloir glycosyltransferases and natural product glycosylation: Biocatalytic synthesis of the $\mathrm{C}$-glucoside 
nothofagin, a major antioxidant of redbush herbal tea. Adv Synth Catal 2013; 355: 2757-2763

[65] Bungaruang L, Gutmann A, Nidetzky B. $\beta$-Cyclodextrin improves solubility and enzymatic C-glucosylation of the flavonoid phloretin. Adv Synth Catal 2016; 358: 486-493

[66] Eichenberger M, Lehka B], Folly C, Fischer D, Martens S, Simón E, Naesby M. Metabolic engineering of Saccharomyces cerevisiae for de novo production of dihydrochalcones with known antioxidant, antidiabetic, and sweet tasting properties. Metab Eng 2017; 39: 80-89

[67] Lipinski CA, Lombardo F, Dominy BW, Feeney PJ. Experimental and computational approaches to estimate solubility and permeability in drug discovery and development settings. Adv Drug Deliv Rev 1997; 23: 3-25

[68] Di L, Kerns EH. Profiling drug-like properties in discovery research. Curr Opin Chem Biol 2003; 7: 402-408

[69] Veber DF, Johnson SR, Cheng HY, Smith BR, Ward KW, Kopple KD. Molecular properties that influence the oral bioavailability of drug candidates. J Med Chem 2002; 45: 2615-2623

[70] Courts FL, Williamson G. The occurrence, fate and biological activities of C-glycosyl flavonoids in the human diet. Crit Rev Food Sci Nutr 2015; 10 : $1352-1367$

[71] Van der Merwe JD, Joubert E, Manley M, De Beer D, Malherbe C], Gelderblom WCA. In vitro hepatic biotransformation of aspalathin and nothofagin, dihydrochalcones of rooibos (Aspalathus linearis), and assessment of metabolite antioxidant activity. J Agric Food Chem 2010; 58: $2214-2220$

[72] Courts FL, Williamson G. The C-glycosyl flavonoid, aspalathin, is absorbed, methylated and glucuronidated intact in humans. Mol Nutr Food Res 2009; 53: 1104-1111

[73] Kreuz S, Joubert E, Waldmann KH, Ternes W. Aspalathin, a flavonoid in Aspalathus linearis (rooibos), is absorbed by pig intestine as a C-glycoside. Nutr Res 2008; 28: 690-701

[74] Gonzales GB, Van Camp J, Vissenaekens H, Raes K, Smagghe G, Grootaert C. Review on the use of cell cultures to study metabolism, transport, and accumulation of flavonoids: from mono-cultures to coculture systems. Compr Rev Food Sci Food Saf 2015; 14: 741-754

[75] Braune A, Blaut M. Deglycosylation of puerarin and other aromatic Cglucosides by a newly isolated human intestinal bacterium. Environ Microbiol 2011; 13: 482-494

[76] Sanugul K, Akao T, Li Y, Kakiuchi N, Nakamura N, Hattori M. Isolation of a human intestinal bacterium that transforms mangiferin to norathyriol and inducibility of the enzyme that cleaves a C-glucosyl bond. Biol Pharm Bull 2005; 28: 1672-1678

[77] Nakamura K, Nishihata T, Jin JS, Ma CM, Komatsu K, Iwashima M, Hattori $\mathrm{M}$. The C-glucosyl bond of puerarin was cleaved hydrolytically by a human intestinal bacterium strain PUE to yield its aglycone daidzein and an intact glucose. Chem Pharm Bull 2011; 59: 23-27

[78] Braune A, Blaut M. Intestinal bacterium Eubacterium cellulosolvens deglycosylates flavonoid C- and O-glucosides. Appl Environ Microbiol 2012; 78: 8151-8153

[79] World Health Organization. World health statistics 2012. World Health Organization. Available at http://apps.who.int/iris/bitstream/10665/ 44844/1/9789241564441_eng.pdf?ua=1. Accessed September 25, 2017

[80] Grundy SM, Brewer HB, Cleeman JI, Smith SC, Lenfant C. Definition of metabolic syndrome: Report of the National Heart, Lung, and Blood Institute/American Heart Association conference on scientific issues related to definition. Circulation 2004; 109: 433-438

[81] GBD 2015 Obesity Collaborators. Health effects of overweight and obesity in 195 countries over 25 years. N Engl ] Med 2017; 377: 13-27

[82] International Diabetes Federation. IDF diabetes atlas, 7th Edition. International Diabetes Federation. Available at https://www.idf.org/e-library/ epidemiology-research/diabetes-atlas/13-diabetes-atlas-seventhedition.html. Accessed September 25, 2017
[83] Cerf ME. Beta cell dysfunction and insulin resistance. Front Endocrinol 2013; 4: 37

[84] Bugianesi E, McCullough AJ, Marchesini G. Insulin resistance: a metabolic pathway to chronic liver disease. Hepatology 2005; 42: 9871000

[85] Monteiro R, Azevedo I. Chronic inflammation in obesity and the metabolic syndrome. Mediators Inflamm 2010; 2010: 289645

[86] Aude YW, Mego P, Mehta JL. Metabolic syndrome: dietary interventions. Curr Opin Cardiol 2004; 19: 473-479

[87] Ren J, Zhu W, Dai H, Chen Z, Chen L, Fang L. Nutritional intervention in the metabolic syndrome. Asia Pac J Clin Nutr 2007; 16: 418-421

[88] Dludla PV, Muller CJF, Joubert E, Louw J, Essop MF, Gabuza KB, Ghoor S, Huisamen B, Johnson R. Aspalathin protects the heart against hyperglycemia-induced oxidative damage by up-regulating Nrf2 expression. Molecules 2017; 22: E129

[89] Zhang Z, Zhou S, Jiang X, Wang YH, Li F, Wang YG, Zheng Y, Cai L. The role of the Nrf2/Keap1 pathway in obesity and metabolic syndrome. Rev Endocr Metab Disord 2015; 16: 35-45

[90] Tang W, jiang YF, Ponnusamy M, Diallo M. Role of Nrf2 in chronic liver disease. World J Gastroenterol 2014; 20: 13079-13087

[91] Johnson R, Dludla P, Muller C, Huisamen B, Essop M, Louw J. The transcription profile unveils the cardioprotective effect of aspalathin against lipid toxicity in an in vitro H9c2 model. Molecules 2017; 22: E219

[92] Mazibuko SE, Joubert E, Johnson R, Louw J, Opoku AR, Muller CJF. Aspalathin improves glucose and lipid metabolism in 3T3-L1 adipocytes exposed to palmitate. Mol Nutr Food Res 2015; 59: 2199-2208

[93] Yuan G, Wahlqvist ML, He G, Yang M, Li D. Natural products and antiinflammatory activity. Asia Pac J Clin Nutr 2006; 15: 143-152

[94] Roberts CK, Hevener AL, Barnard RJ. Metabolic syndrome and insulin resistance: underlying causes and modification by exercise training. Compr Physiol 2013; 3: 1-58

[95] Dimitriadis G, Mitrou P, Lambadiari V, Maratou E, Raptis SA. Insulin effects in muscle and adipose tissue. Diabetes Res Clin Pract 2011; 93: S52-S59

[96] Fang X, Yu SX, Lu Y, Bast RC, Woodgett JR, Mills GB. Phosphorylation and inactivation of glycogen synthase kinase 3 by protein kinase $A$ Proc Natl Acad Sci U S A 2000; 97: 11960-11965

[97] Cho H, Thorvaldsen JL, Chu Q, Feng F, Birnbaum MJ. Akt1/PKB $\alpha$ is required for normal growth but dispensable for maintenance of glucose homeostasis in mice. J Biol Chem 2001; 276: 38349-38352

[98] Ruderman NB, Carling D, Prentki M, Cacicedo JM. AMPK, insulin resistance, and the metabolic syndrome. J Clin Invest 2013; 123: 2764 2772

[99] Huang S, Czech MP. The GLUT4 glucose transporter. Cell Metab 2007; 5: 237-252

[100] O’Neill HM. AMPK and exercise: glucose uptake and insulin sensitivity. Diabetes Metab J 2013; 37: 1-21

[101] Kim J, Yang G, Kim Y, Kim J, Ha J. AMPK activators: mechanisms of action and physiological activities. Exp Mol Med 2016; 48: e224

[102] Johnson R, Dludla P, Joubert E, February F, Mazibuko S, Ghoor S, Muller C, Louw J. Aspalathin, a dihydrochalcone C-glucoside, protects H9c2 cardiomyocytes against high glucose induced shifts in substrate preference and apoptosis. Mol Nutr Food Res 2016; 60: 922-934

[103] Viollet B, Horman S, Leclerc ], Lantier L, Foretz M, Billaud M, Giri S, Andreelli F. AMPK inhibition in health and disease. Crit Rev Biochem Mol Biol 2010; 45: 276-295

[104] Dyck JRB, Lopaschuk GD. AMPK alterations in cardiac physiology and pathology: enemy or ally? J Physiol 2006; 574: 95-112

[105] Wakil SJ, Abu-Elheiga LA. Fatty acid metabolism: target for metabolic syndrome. J Lipid Res 2009; 50: S138-S143 
[106] Frayn KN, Arner P, Yki-Jarvinen H. Fatty acid metabolism in adipose tissue, muscle and liver in health and disease. Essays Biochem 2006; 42 : 89-103

[107] Serra D, Mera P, Malandrino MI, Mir JF, Herrero L. Mitochondrial fatty acid oxidation in obesity. Antioxid Redox Signal 2013; 19: 269-284

[108] Lara-Castro C, Garvey WT. Intracellular lipid accumulation in liver and muscle and the insulin resistance syndrome. Endocrinol Metab Clin North Am 2008; 37: 841-856

[109] Turner N, Cooney G], Kraegen EW, Bruce CR. Fatty acid metabolism, energy expenditure and insulin resistance in muscle. J Endocrinol 2014; 220: T61-T79

[110] Giacco F, Brownlee M. Oxidative stress and diabetic complications. Circ Res 2010; 107: 1058-1070

[111] Lu SC. Regulation of glutathione synthesis. Mol Aspects Med 2009; 30: 42-59

[112] Pham-Huy L, He H, Pham-Huy C. Free radicals, antioxidants in disease and health. Int J Biomed Sci 2008; 4: 89-96

[113] Niedowicz DM, Daleke DL. The role of oxidative stress in diabetic complications. Cell Biochem Biophys 2005; 43: 289-330

[114] Rani V, Deep G, Singh RK, Palle K, Yadav UCS. Oxidative stress and metabolic disorders: Pathogenesis and therapeutic strategies. Life Sci 2016; 148: 183-193

[115] Newsholme P, Cruzat VF, Keane KN, Carlessi R, De Bittencourt PIH. Molecular mechanisms of ROS production and oxidative stress in diabetes. Biochem J 2016; 473: 4527-4550

[116] Yesilbursa D, Serdar Z, Serdar A, Sarac M, Coskun S, Jale C. Lipid peroxides in obese patients and effects of weight loss with orlistat on lipid peroxides levels. Int J Obes 2005; 29: 142-145

[117] Avci E, Avci GA, Cevher SC. The role of malondialdehyde and glutathione in metabolic syndrome's complications. J Biotechnol 2017; 256: $\$ 32$

[118] Caimi G, Hopps E, Montana M, Noto D, Canino B, Lo Presti R, Averna MR. Evaluation of nitric oxide metabolites in a group of subjects with metabolic syndrome. Diabetes Metab Syndr Clin Res Rev 2012; 6: 132-135

[119] Nour Eldin EE, Almarzouki A, Assiri A, Elsheikh O, Mohamed BE, Babakr A. Oxidized low density lipoprotein and total antioxidant capacity in type-2 diabetic and impaired glucose tolerance Saudi men. Diabetol Metab Syndr 2014; 6: 94

[120] McArdle MA, Finucane OM, Connaughton RM, McMorrow AM, Roche HM. Mechanisms of obesity-induced inflammation and insulin resistance: Insights into the emerging role of nutritional strategies. Front Endocrinol 2013; 4: 52

[121] DeBoer MD. Obesity, systemic inflammation, and increased risk for cardiovascular disease and diabetes among adolescents: a need for screening tools to target interventions. Nutrition 2013; 29: 379-386

[122] Moreno-Indias I, Tinahones FJ. Impaired adipose tissue expandability and lipogenic capacities as ones of the main causes of metabolic disorders. J Diabetes Res 2015; 2015: 970375

[123] Jung U, Choi MS. Obesity and its metabolic complications: the role of adipokines and the relationship between obesity, inflammation, insulin resistance, dyslipidemia and nonalcoholic fatty liver disease. Int J Mol Sci 2014; 15: 6184-6223

[124] Kwon H, Pessin JE. Adipokines mediate inflammation and insulin resistance. Front Endocrinol 2013; 4: 71

[125] De Ferranti S, Mozaffarian D. The perfect storm: obesity, adipocyte dysfunction, and metabolic consequences. Clin Chem 2008; 54: 945955

[126] Sharma A, Holland W. Adiponectin and its hydrolase-activated receptors. J Nat Sci 2017; 3: e396
[127] Liu C, Feng X, Li Q, Wang Y, Li Q, Hua M. Adiponectin, TNF- $\alpha$ and inflammatory cytokines and risk of type 2 diabetes: A systematic review and meta-analysis. Cytokine 2016; 86: 100-109

[128] Popa C, Netea MG, van Riel PL, van der Meer JWM, Stalenhoef AFH. The role of TNF- $\alpha$ in chronic inflammatory conditions, intermediary metabolism, and cardiovascular risk. J Lipid Res 2007; 48: 751-762

[129] Lee S, Kwak HB. Role of adiponectin in metabolic and cardiovascular disease. J Exerc Rehabil 2014; 10: 54-59

[130] Tsatsanis C, Zacharioudaki V, Androulidaki A, Dermitzaki E, Charalampopoulos I, Minas V, Gravanis A, Margioris AN. Adiponectin induces TNF- $\alpha$ and IL- 6 in macrophages and promotes tolerance to itself and other pro-inflammatory stimuli. Biochem Biophys Res Commun 2005; 335: 1254-1263

[131] Tzanavari T, Giannogonas P, Karalis KP. TNF- $\alpha$ and Obesity. In: Kollias G Sfikakis P, edis. TNF Pathophysiology. Molecular and cellular Mechanisms. Basel, Switzerland: Karger; 2010: 145-156

[132] Pacifico L, Chiesa C, Anania C, De Merulis A, Osborn JF, Romaggioli S, Gaudio E. Nonalcoholic fatty liver disease and the heart in children and adolescents. World J Gastroenterol 2014; 20: 9055-9071

[133] Makki K, Froguel P, Wolowczuk I. Adipose tissue in obesity-related inflammation and insulin resistance: cells, cytokines, and chemokines. ISRN Inflamm 2013; 2013: 139239

[134] Buzzetti E, Pinzani M, Tsochatzis EA. The multiple-hit pathogenesis of non-alcoholic fatty liver disease (NAFLD). Metabolism 2016; 65: 1038 1048

[135] Diraison F, Dusserre E, Vidal H, Sothier M, Beylot M. Increased hepatic lipogenesis but decreased expression of lipogenic gene in adipose tissue in human obesity. Am J Physiol Endocrinol Metab 2002; 282: E46E51

[136] Dichtl W, Nilsson L, Goncalves I, Ares MPS, Banfi C, Calara F, Hamsten A, Eriksson P, Nilsson J. Very low-density lipoprotein activates nuclear factor-kB in endothelial cells. Circ Res 1999; 84: 1085-1094

[137] Lorenzon P, Vecile E, Nardon E, Ferrero E, Harlan JM, Tedesco F, Dobrina A. Endothelial cell E- and P-selectin and vascular cell adhesion molecule-1 function as signaling receptors. J Cell Biol 1998; 142: 13811391

[138] Amiot M], Riva C, Vinet A. Effects of dietary polyphenols on metabolic syndrome features in humans: a systematic review. Obes Rev 2016; 17: $573-586$

[139] Kawano A, Nakamura H, Hata S, Minakawa M, Miura Y, Yagasaki K. Hypoglycemic effect of aspalathin, a rooibos tea component from Aspalathus linearis, in type 2 diabetic model $\mathrm{db} / \mathrm{db}$ mice. Phytomedicine 2009; 16: 437-443

[140] Muller CJF, Joubert E, De Beer D, Sanderson M, Malherbe C], Fey S], Louw J. Acute assessment of an aspalathin-enriched green rooibos (Aspalathus linearis) extract with hypoglycemic potential. Phytomedicine 2012; 20: 32-39

[141] Mikami N, Tsujimura J, Sato A, Narasada A, Shigeta M, Kato M, Hata S Hitomi E. Green rooibos extract from Aspalathus linearis, and its component, aspalathin, suppress elevation of blood glucose levels in mice and inhibit $\alpha$-amylase and $\alpha$-glucosidase activities in vitro. Food Sci Technol Res 2015; 21: 231-240

[142] Mazibuko SE, Muller CJF, Joubert E, De Beer D, Johnson R, Opoku AR, Louw J. Amelioration of palmitate-induced insulin resistance in $\mathrm{C} 2 \mathrm{C} 12$ muscle cells by rooibos (Aspalathus linearis). Phytomedicine 2013; 20: 813-819

[143] Son MJ, Minakawa M, Miura Y, Yagasaki K. Aspalathin improves hyperglycemia and glucose intolerance in obese diabetic ob/ob mice. Eur J Nutr 2013; 52: 1607-1619

[144] Smit S, Johnson R, Van Vuuren M, Huisamen B. Myocardial glucose clearance by aspalathin treatment in young, mature, and obese insulin-resistant rats. Planta Med 2018; 84: 75-83 
[145] Johnson R, Shabalala S, Louw J, Kappo A, Muller C. Aspalathin reverts doxorubicin-induced cardiotoxicity through ncreased autophagy and decreased expression of p53/mTOR/p62 Signaling. Molecules 2017; 22: E1589

[146] Najafian M, Najafian B, Najafian Z. The effect of aspalathin on levels of sugar and lipids in streptozotocin-induced diabetic and normal rats. Zahedan J Res Med Sci 2016; 18: e4963

[147] Van der Merwe J, De Beer D, Joubert E, Gelderblom W. Short-term and sub-chronic dietary exposure to aspalathin-enriched green rooibos (Aspalathus linearis) extract affects rat liver function and antioxidant status. Molecules 2015; 20: 22674-22690

[148] Oikari S, Ahtialansaari T, Heinonen MV, Mauriala T, Auriola S, Kiehne K, Fölsch UR, Jänne J, Alhonen L, Herzig KH. Downregulation of PPARs and SREBP by acyl-CoA-binding protein overexpression in transgenic rats. Pflügers Arch 2008; 456: 369-377

[149] Yang G, Lee J, Lee S, Kwak D, Choe W, Kang I, Kim SS, Ha J. Krill oil supplementation improves dyslipidemia and lowers body weight in mice fed a high-fat diet through activation of AMP-activated protein kinase. J Med Food 2016; 19: 1120-1129

[150] Hardie DG. Regulation of AMP-activated protein kinase by natural and synthetic activators. Acta Pharm Sin B 2016; 6: 1-19

[151] Van der Merwe JD, De Beer D, Joubert E, Gelderblom WCA. Erratum: Short-term and sub-chronic dietary exposure to aspalathin-enriched green rooibos (Aspalathus linearis) extract affects rat liver function and antioxidant status. Molecules 2016; 21: E907

[152] Chen W, Sudji IR, Wang E, Joubert E, Van Wyk BE, Wink M. Ameliorative effect of aspalathin from rooibos (Aspalathus linearis) on acute oxidative stress in Caenorhabditis elegans. Phytomedicine 2013; 20: 380 386

[153] Kondo M, Hirano Y, Nishio M, Furuya Y, Nakamura H, Watanabe T. Xanthine oxidase inhibitory activity and hypouricemic effect of aspalathin from unfermented rooibos. J Food Sci 2013; 78: H1935-H1939

[154] Orlando P, Chellan N, Muller C, Louw J, Chapman C, Joubert E, Tiano L. Green rooibos extract improves plasma lipid profile and oxidative status in diabetic non-human primates. Free Radic Biol Med 2017; 108: S96-S97

[155] Marnewick JL, Rautenbach F, Venter I, Neethling H, Blackhurst DM, Wolmarans P, Macharia M. Effects of rooibos (Aspalathus linearis) on oxidative stress and biochemical parameters in adults at risk for cardiovascular disease. J Ethnopharmacol 2011; 133: 46-52
[156] Ku SK, Lee W, Kang M, Bae JS. Antithrombotic activities of aspalathin and nothofagin via inhibiting platelet aggregation and Flla/FXa. Arch Pharm Res 2015; 38: 1080-1089

[157] Ku SK, Kwak S, Kim Y, Bae JS. Aspalathin and nothofagin from rooibos (Aspalathus linearis) inhibits high glucose-induced inflammation in vitro and in vivo. Inflammation 2015; 38: 445-455

[158] Lee W, Kim KM, Bae JS. Ameliorative effect of aspalathin and nothofagin from rooibos (Aspalathus linearis) on HMGB1-induced septic responses in vitro and in vivo. Am J Chin Med 2015; 43: 991-1012

[159] Kurosawa S, Stearns-Kurosawa D, Carson C, D’Angelo A, Della Valle P, Esmon C. Plasma levels of endothelial cell protein $C$ receptor are elevated in patients with sepsis and systemic lupus erythematosus: lack of correlation with thrombomodulin suggests involvement of different pathological processes. Blood 1998; 91: 725-728

[160] White C. Inhibitory Effect of selected herbal Supplements on CYP450 mediated Metabolism - an in vitro Approach [MSc in Pharmacology thesis]. Stellenbosch, South Africa: Stellenbosch University; 2016

[161] Dludla PV, Muller CJF, Louw J, Joubert E, Salie R, Opoku AR, Johnson R. The cardioprotective effect of an aqueous extract of fermented rooibos (Aspalathus linearis) on cultured cardiomyocytes derived from diabetic rats. Phytomedicine 2014; 21: 595-601

[162] Lee W, Bae JS. Anti-inflammatory effects of aspalathin and nothofagin from rooibos (Aspalathus linearis) in vitro and in vivo. Inflammation 2015; 38: 1502-1516

[163] Kwak S, Han MS, Bae JS. Aspalathin and nothofagin from rooibos (Aspalathus linearis) inhibit endothelial protein $C$ receptor shedding in vitro and in vivo. Fitoterapia 2015; 100: 179-186

[164] Fugh-Berman A. Herb-drug interactions. Lancet 2000; 355: 134-138

[165] Sinisalo M, Enkovaara AL, Kivistö KT. Possible hepatotoxic effect of rooibos tea: a case report. Eur J Clin Pharmacol 2010; 66: 427-428

[166] Engels M, Wang C, Matoso A, Maidan E, Wands J. Tea not tincture: hepatotoxicity associated with rooibos herbal tea. ACG Case Reports J 2013; 1: 58-60

[167] Zacharia CC, Whitlatch H. Rooibos herbal tea linked to hepatotoxicity and severe hypercholesterolemia. Endocrinol Rev 2013; 34: SUN-730

[168] Patel O, Muller C, Joubert E, Louw J, Rosenkranz B, Awortwe C. Inhibitory interactions of Aspalathus linearis (rooibos) extracts and compounds, aspalathin and Z-2-( $\beta$-D-glucopyranosyloxy)-3-phenylpropenoic acid, on cytochromes metabolizing hypoglycemic and hypolipidemic drugs. Molecules 2016; 21: E1515 